Portland State University

PDXScholar

$5-24-1985$

\title{
Aspects of Cardiovascular Oxygen Transport in Vertebrates
}

Michael Scott Hedrick

Portland State University

Follow this and additional works at: https://pdxscholar.library.pdx.edu/open_access_etds

Part of the Biology Commons, and the Cardiovascular System Commons Let us know how access to this document benefits you.

\section{Recommended Citation}

Hedrick, Michael Scott, "Aspects of Cardiovascular Oxygen Transport in Vertebrates" (1985). Dissertations and Theses. Paper 3404.

https://doi.org/10.15760/etd.5291

This Thesis is brought to you for free and open access. It has been accepted for inclusion in Dissertations and Theses by an authorized administrator of PDXScholar. Please contact us if we can make this document more accessible: pdxscholar@pdx.edu. 
AN ABSTRACT OF THB THBSIS OF Michael Scott Hedrick for the Kaster of Science in Biology presented May 24, 1985.

Title: Aspects of Cardiovascular Oxygen Tranoport in Vertebrates APPROVED BY MEMBERS OF THE THESIS COMITTEE:

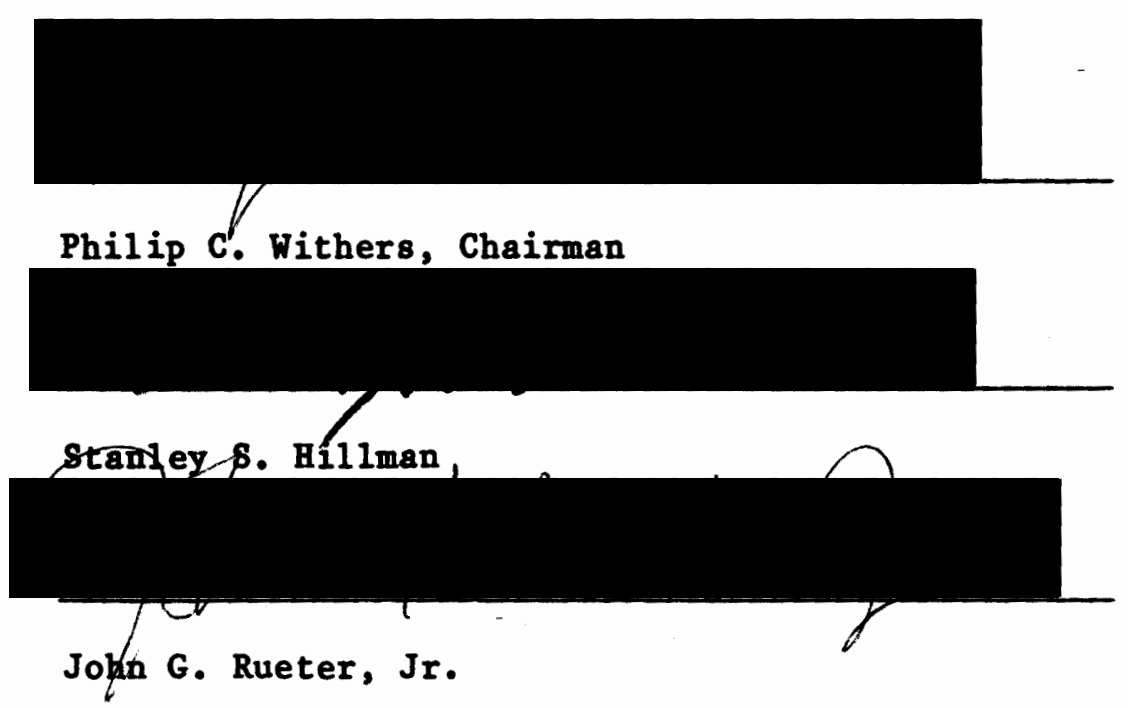

The hematological and rheological characteristics of blood from a number of vertebrates was compared to as8ess possible species differences in blood viscosity that may influence cardiovascular oxygen transport. Nucleated red blood cells ( $\mathrm{BBC}$ ) were more viscous (measured by cone-plate iscometry) in comparison with enucleate (mammalian) RBCs at hematocrits greater than $40 \%$ when measured at equivalent temperatures. The lower viscosity of enucleate RBCs is attributed to an enhanced deformability of enucleate cells in comparison to nucleated cells. 
The predicted in vitro optimal hematocrit (Ho) for oxygen transport was determined for each species and compared to the observed in vivo hematocrit (Hct). There was a very close correspondence between the predicted Bo and the observed normal Bct for the blood tested, with the exception of elephant seal (Yirounge angustirostrig) blood.

Resting and maximal rates of blood flow at $100^{\circ} \mathrm{C}, 200^{\circ} \mathrm{C}$ and $30^{\circ} \mathrm{C}$ vere measured in Bufo marinus with magnetic blood flow probes to assess the relative contributions of heart rate, systemic arch pulse volume and arteriovenous (A- $\nabla)$ oxygen difference to increased oxygen consumption ( $\nabla 02)$. A- $\nabla 02$ difference accounted for $100 \%, 84 \%$ and $88 \%$ of the increase in 802 during maximal exercise at $100^{\circ} \mathrm{C}, 20^{\circ} \mathrm{C}$ and $30^{\circ} \mathrm{C}$, respectively.

Systemic arch pulse volume remained nearly constant over a wide range of heart rates ( $15-115$ beats min $\left.^{-1}\right)$ thus contributing little to increased cardiac output during increased v02.

Changes in blood flow rates through the systemic arches of resting toads were predicted by in vitro changes in blood viscosity over a $10^{\circ} \mathrm{C}$ to $300 \mathrm{C}$ interval. Resting animals did not appear to actively compensate for the passive alterations in viscosity that seemed to influence blood flow rates in vivo. 
ASPECTS OF CARDIOVASCULAR OXYGEN

TRANSPORT IN VERTEBRATES

by

MICHAEL SCOTT HEDRICK

A thesis submitted in partial fulfillment of the requirements for the degree of

MASTER OF SCIENCE

in

B IOLOGY

Portland State University

1985 
TO THE OFFICE OR GRADOATE STUDIES AND RESEARCH:

The members of the Committee approve the thesis of Michael Scott Hedrick presented May 24, 1985.

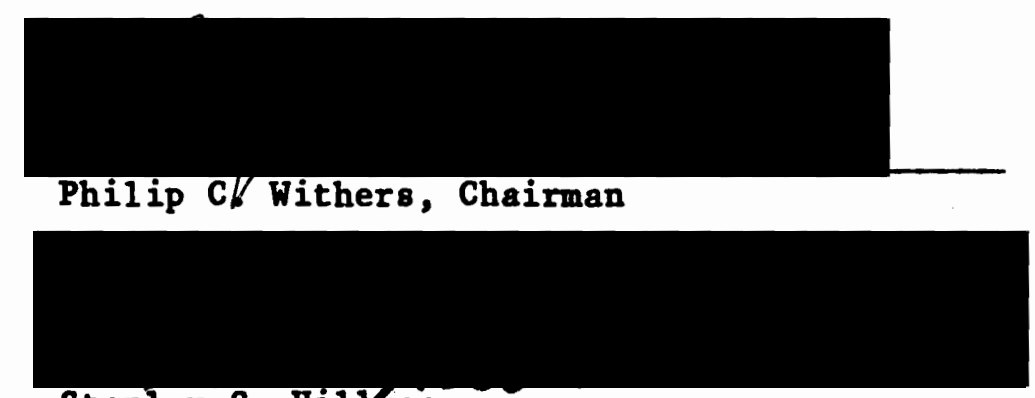

Stanley S. Hilyman

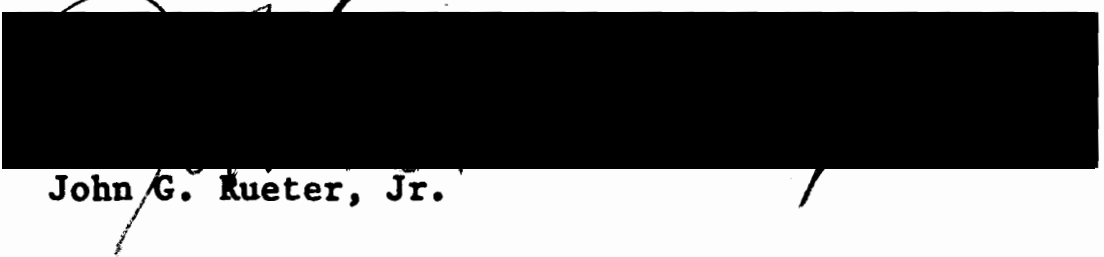

APPROVED :

W. Herman Taylor, Head, Department of Biology

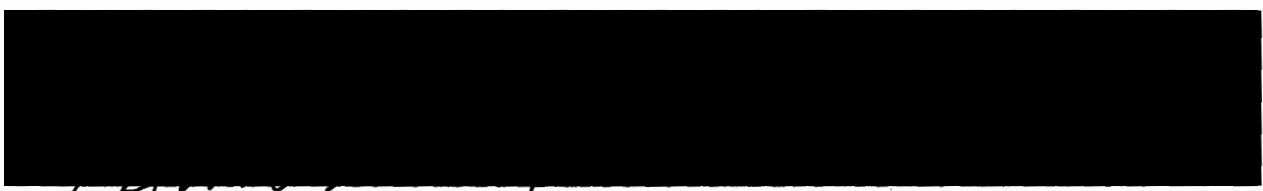

Heath, Dean of Graduate Studies and Research 


\section{ACKNOWLEDGEMENTS}

I am deeply indebted to my advisor and friend, Phil Withers, for his guidance, encouragement and help, particularly "down the home stretch" when I needed it the most. I also owe much thanks to Stanley for introducing me to Fog's, squash and a sense of what graduate work is al1 about.

I also would like to thank my parents for their never ending support of my endeavors.

And finally, without Amy's patience, understanding and especially, assistance, this thesis might never have been completed. 
TABLE OF CONTENTS

PAGE

ACKNOWLEDGEMENTS..........................

iii

IIST OF TABLES...........................

vi

LIST OF FIGURES.

viii

INTRODUCTION

1

CHAPTER I: COMPARATIVE BLOOD RHEOLOGY OF VERTEBRATES

AND OPTIMAL HEMATOCRIT THEORY

INIRODUCTION........................... 5

MATERIALS AND METHODS.................... 7

Anima1s............................ 7

Hematocrit and Viscosity................. 8

Hemoglobin and Plasma Protein.............. 9

Statistics.......................... 10

RESULTS.............................. 10

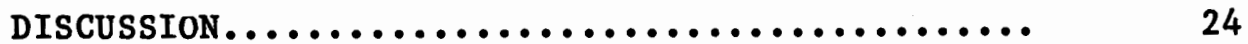

Optimal Hematocrit for Oxygen Transport....... 28

CHAPTER II: THE EFFECTS OF TEMPERATURE AND ACTIVITY

ON HEART RATE, BLOOD FLOW RATE AND BLOOD VISCOSITY

IN BUFO MARINUS

INTRODUCTION ............................. 34

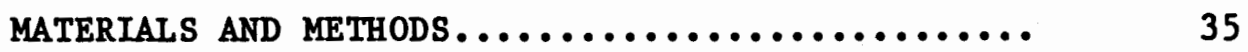

Animals............................. 35 
Blood Flow Rates....................... 35

Blood Flow Rates at Low and High Temperatures. 36

Standard and Active Metabolic Rates......... 37

Blood Viscosity...................... 38

Statistics......................... 38

RESULTS............................ 38

Heart Rate, Systemic Arch Pulse Volume and

Blood Flow Rates....................... 38

Metabolic Rates....................... 43

Blood Viscosity....................... 48

DISCUSSION............................ 48

Heart Rate, Systemic Arch Pulse Volume and

Oxygen Consumption...................... 48

Blood Flow Rates and Viscosity............. 57

SUMMARY............................... 64

REFERENCES........................... 66 


\section{LIST OF TABLES}

I Values for Hematocrit (Hct; \%), Hemoglobin concentration (Hb; $g \%$ ), Mean Cell Hemoglobin Concentration (MCHC; $g \%)$, Blood viscosity $\left(n_{b \mid} ; c P\right)$, Plasma viscosity $\left(\eta_{p l} ; c P\right)$ and total protein $(g \%)$ for each of the species used in this study. Values are mean \pm S.E., with sample size (N)... Slopes ( \pm 2 S.E.) and intercepts $( \pm 2$ S.E.) for the log-transformed relationship between viscosity and hematocrit for the species examined in this study.

III Measurement of observed hematocrit (Hct;\%), predicted in vitro optimal hematocrit (Ho; \%), range of Hets for $95 \%$ of maximum oxygen transport capacity (OTC) and the percent deviation of observed Hct compared to the predicted Ho.

IV Cardiovascular variables measured for Bufo marinus. Values are mean \pm S.E. Number of observations $(\mathrm{N})$ is also given...............

$\nabla \quad$ Metabolic Rates ( $\mathrm{V02} ; \mathrm{ml} 02 \mathrm{~g}^{-1} \mathrm{~h}^{-1}$ ) of resting and active toads. Values are mean \pm S.E. and number of observations(N). The absolute metabolic scope (active-resting), 
factorial scope (active/resting) and Q10

values are also given... 


\section{LIST OF FIGURES}

FIGURE

PAGE

1. Viscosity (centipoise; $C P$ ) as a function of hematocrit (\% cells) for the species examined in this study. Viscosity measurements were determined at a shear rate of $450 \mathrm{sec}^{-1}$. Curvilinear regressions were determined from the equations in Table II..........

2. Viscosity (centipoise; $c P$ ) as a function of temperature $(O C)$ for salmon $(\Delta)$, rabbit $(\bullet)$ and chicken blood(D). Numbers indicate the hematocrit at which the measurements were taken. Shear rate was 450 sec $-1 \ldots \ldots \ldots \ldots \ldots \ldots \ldots \ldots \ldots \ldots \ldots \ldots \ldots$

3. Square root of shear stress $\left(\zeta^{1 / 2}\right)$ as a function of the square root of shear rate $\left(y^{1 / 2}\right)$. Mean values ( \pm 2 S.E.) were determined at a hematocrit

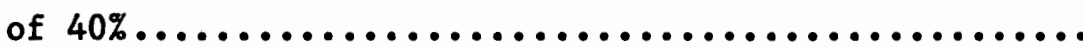

4. Oxygen transport capacity in $\mathrm{ml} 02(100 \mathrm{ml}$ blood cP)-1 as a function of hematocrit (\% cells)...

5. Heart Rate (beats min-1) as a function of temperature (OC) for Bufo marinus at rest (closed circles) and during activity (open circles). Values are mean \pm 2 S.E. 
erature $\left({ }^{\circ} \mathrm{C}\right)$ for $\underline{B}$. marinus at rest (closed circles) and during activity (open circles). Mean values \pm 2 S.E. are also indicated........... 46

7. Systemic arch pulse volume $\left(\mathrm{ml} \mathrm{kg}^{-1}\right)$ as a function of heart rate (beats $\min ^{-1}$ ) for resting (open symbols) and active (closed symbols) $\underline{B}$, marinus at $10^{\circ} \mathrm{C} . . .$. 50

8. Systemic arch pulse volume $\left(\mathrm{ml} \mathrm{kg}^{-1}\right)$ as a function of heart rate (beats $\min ^{-1}$ ) at $20^{\circ} \mathrm{C}$. Regression lines are drawn for animals at which more than two values for pulse volume and heart rate were measured.

9. Systemic arch pulse volume (ml kg-1) as a function of heart rate (beats $\min ^{-1}$ ) for $\underline{B}$. marinus at $30{ }^{\circ} \mathrm{C}$. Regressions are indicated by dashed lines for animals at which more than two values were measured................................

10. Mean values for blood flow rate $\left(\mathrm{ml} \mathrm{kg} \mathrm{kg}^{-1} \mathrm{~min}^{-1}\right)$ for resting (solid bars) and active (open bars) $\underline{B}$. marinus at $100 \mathrm{C}, 20^{\circ} \mathrm{C}$ and $300^{\circ}$. Inset boxes indicate \pm 2 S.E............................

11. The product of blood flow and blood viscosity (ml $\mathrm{kg}^{-1} \mathrm{~min}^{-1} \mathrm{cP}$ ) as a function of temperature $\left({ }^{\circ} \mathrm{C}\right)$ for resting (closed circles) and active (open circles) B. marinus. Values ar mean \pm 2 S.E....... 


\section{INTRODUCTION}

Vertebrates predominately rely on cardiovascular oxygen transport to support aerobic metabol18m, and have developed an array of circulatory capabilities reflective of their ecologically relevant demands for oxygen. Oxygen transport capacity (OTC) of blood is the product of blood flow and blood oxygen content (BOC). BOC is determined by the concentration of blood hemoglobin ( $\mathrm{Hb}$ ) and the percentage of red blood cells (RBCs) in whole blood (Hematocrit; Hct), while blood flow is dependent upon the interaction of blood pressure and circulatory peripherial resistance.

One potentially important aspect of the circulation that impinges on OTC is blood viscosity. Blood viscosity is important in vertebrate circulatory dynamics because it represents a major portion of the total peripheral resistance to blood flow and, hence, orc.

Blood is a suspension of deformable RBCs in plasma. Blood viscosity is dependent upon the velocity of flow (shear rate). At low shear rates aggregations of $\mathrm{RBC}$ ( viscosity than at high rates of shear, when the reversible rouleaux formations break apart and viscosity decreases. Th1s shear dependent behavior of blood characterizes it as a non-Newtonian fluid (Chien, 1975).

Blood viscosity is also dependent upon a number of other factors, including plasma viscosity (Goldsmith and Skalak, 1975), temperature 
(Barbee, 1973; Chen and Chren, 1978), the detormability of RBCs (Chien et a1., 1967) and the blood Hct (Cerny et al., 1962; Skalak et al., 1972).

It has been shown that the flow of blood is inversely proportional to blood viscosity and may be described by the Poiseuille-Hagen flow equation (see Chapter 1). It would appear then that changes in blood viscosity due to the atorementioned variables might play an important role in determining the OTC of vertebrate circulatory systems.

One of the most important determinants of OTC in vertebrates is the Hct since it affects both blood flow and BOC. The effect of Hct on overall OTC in vitro is such that a theoretical optimal Hct (Ho) exists where OTC is maximal (Crowell and Smith, 1967). It appears that despite the wide variations among vertebrates in Hct and blood flow, the normal in vivo Hct is usually equivalent to the predicted Ho determined in vitro (Stone et al., 1968, Snyder, 1971; Weathers, 1976a; Snyder and Weathers, 1977). It is not clear, however, if this correlation is true for all vertebrates since this relationship has been determined for only a few animals.

Temperature is another important variable that affects blood viscosity. Th1s is especially true for animals whose body temperature (Tb) is dependent upon the environmental temperature. In vitro measurements of blood viscosity over a large range of temperatures $\left(5^{\circ} \mathrm{C}-40^{\circ} \mathrm{C}\right)$ indicate that viscosity may change $2-3$

fold, at a given shear rate and Hct (Langille and Crisp, 1980). This would suggest that ectotherms whose Tbs vary either daily or seasonally will experience fluctuations in blood viscosity and concomitant changes 
in blood flow rates in vivo. There do not appear to be data available correlating in vivo blood flow rates and in vitro measurements of blood viscosity in ectotherms, although some measurements of blood flow changes with Tb have been made in endotherms (Chen and Chien, 1978).

In vivo determinations of blood flow in ectotherms would also be useful in determining the nature of cardiovascular adjustments with changes in Tb or activity. The contributions of cardiac output (heart rate $X$ stroke volume) and arteriovenous (A-V) oxygen difference to total oxygen consumption ( $\mathrm{V} 02$ ) in ectotherms are not well established. The relative role of each variable is especially difficult to assess in amphibians due to the possibility of intracardiac shunting of blood, the potential mixing of arterial and venous blood in the undivided ventricle and the cutaneous contribution to oxygenation of blood.

Chapter 1 (Comparative Blood Rheology of Vertebrates and Optimal Hematocrit Theory) examines comparative aspects of blood rheology in a number of vertebrates representing several classes. Based on in vitro measurements of blood viscosity and determinations of BOC, the theoretical Ho is calculated for each species. The predicted Ho was compared with the normal Hct for each species to test the hypothesis that there is a close correlation between the predicted Ho and the normal Hct for vertebrate blood.

Chapter 2 (The Effects of Temperature and Activity on Heart Rate, Blood Flow Rate and Blood Viscosity in Bufo marinus) examines aspects of heart rate and in vivo measurements of blood flow through the systemic arches of Bufo marinus in an attempt to further elucidate the relative contributions of these variables to the increased metabolic demands of 
temperature and exercise. The precise role of these factors to total v02 in amphibians is unclear. The role of blood viscosity in determining in vivo rates of blood flow with changing $\mathrm{Tb}$ in amphibians is also unknown. In vitro measurements of toad blood viscosity were compared with in vivo rates of blood flow during rest and activity from $10^{\circ} \mathrm{C}$ to $30^{\circ} \mathrm{C}$ in order to determine whether changes in blood viscosity with temperature have a significant effect on in vivo blood flow rates in amphibians. 


\title{
CBAPTER I
}

\author{
COMPARATIVE BLOOD RHEOLOGY OF VERTEBRATES \\ AND OPTIMAL HEMATOCRIT THEORY
}

\section{INTRODUCTION}

There are species specific differences in the viscosity of vertebrate blood for ectotherms (Maclean et al., 1975; Graham and Fletcher, 1983; Graham et a1., 1985; Chien et al., 1971) and endotherms (Maclean, 1981; Usami et al., 1969). These species differences are the result of variations in plasma viscosity (Chien, 1970, 1971), the presence or absence of an erythrocyte nucleus (Usami et al., 1970; Gaehtgens et $a 1 ., 1981 \mathrm{a}, \mathrm{b})$ and the shear dependent, non-Newtonian behavior of erythrocytes (Guard and Murrish, 1975; Halikas, 1971; Maclean, 1981).

Maximal blood oxygen transport is the product of blood flow ( $Q b 1)$ and blood oxygen capacity (BOC). Animals vary significantly in BOC due to variation in blood hemoglobin (Bb) concentration. The $\mathrm{Bb}$ concentration of blood is, in turn, determined by the percentage of red blood cells (hematocrit) and the mean cellular Hb concentration (MCHC). In order to increase maximal OTC to the tissues, animals may increase either $Q \mathrm{Bl}$, BOC or both. One consequence of transporting oxygen via erythrocytes is that blood, as a typical fluid, has a viscosity which is dependent upon its RBC concentration. The potential significance of 
blood viscosity to blood flow and oxygen transport in vertebrates has been described by a number of workers (Murray et al., 1962; Stone et al., 1968; Snyder, 1971; Weather8, 1976a; Chien, 1972) and forms the basis for optimal hematocrit theory (Crowell and Smith, 1967). The optimal hematocrit (HO) is defined as the hematocrit that allows the greatest oxygen transport per unit time. The Ho exists because blood viscosity varies exponentially w1th hematocrit, hence blood flow is inversely proportional to blood viscosity, whereas BOC increases 11nearly wath hematocrit. Thus oxygen transport increases with hematocrit to a maximum value then declines as viscosity reduces $Q b l$ at high hematocrits. It has been shown for a number of vertebrates that there is a close correspondence between the observed in vivo hematocrit and tne predicted Ho determined in vitro (Snyder, 1971; Weathers, 1976a; Snyder and Weathers, 1977; Stone et al.., 1968).

The purpose of the study presented in chapter 1 is to examine the comparative aspects of blood rheology (deformation, flow and viscosity) for representative vertebrates from several classes. Species differences in blood viscosity are examined at various temperatures. Based on the hematological and rheological characteristics of the various types of blood, the theoretical Ho is derived and compared to the observed hematocrit of each species.

MATERIALS AND METHODS

\section{Anima18}

Bullfrogs (Rana catesbeiana), marine toads (Bufo marinus) and amphiuma (Amphiuma means) were purchased from commercial suppliers and 
maintained in the laboratory. No attempt was made to control photoperiod. Blood from bullfrogs and toads was removed via a heparinized cannula (PE 90) surgically implanted in the ventral abdominal vein. Amphiuma blood was obtained by cutting the tail and allowing the blood to drain into a heparinized container.

Coho salmon (Oncorhynchus kisutch) blood was obtained at a local fish hatchery (Multnomah Co., Oregon) by removing the tail fin and draining the blood into heparinized containers.

Domestic chickens (Gallus domesticus) were purchased from local suppliers and maintained outdoors. Food and water were provided ad libitum. Blood was removed with a heparinized syringe from a wing vein.

Blood from New Zealand white rabbits (Oryctolagus cuniculus) was provided by the laboratory of Jon Abramson, Department of Physics, Portland State University. Blood was collected by bleeding the animals from the carotid arteries and jugular veins into heparinized containers. Blood samples from Northern Elephant Seals (Mirounga angustirostris) were drawn from captive animals at Sea World (San Diego, California), chilled and flown to Portland for analysis. The blood was analyzed within one day of sampling.

At least three individuals of each species were sampled to determine blood viscosity and hematocrit. Blood samples from several salmon were pooled since blood volume from each animal was low.

\section{Hematocrit and Viscosity}


Hematocrit was determined in triplicate for blood samples from each species after centrifugation for five minutes (Adams Autocrit). No correction was made for trapped plasma.

The viscosity of whole blood was determined for $0.2 \mathrm{ml}$ samples using a Wells-Brookfield cone-plate viscometer (model LVTDCP, cone angle $\left.0.8^{\circ}\right)$. The viscometer was calibrated periodically with a 5.4 centiPoise standard fluid (Brookfield Laboratories) to ensure accuracy. The temperature of the water jacketed sample cup was regulated from $5^{\circ} \mathrm{C}-39^{\circ} \mathrm{C}$ $\left( \pm 1.00^{\circ}\right)$ with a Forma Scientific (model 2095) constant temperature water bath. Viscosity measurements were determined over a range of shear rates $\left(2.25 \mathrm{sec}^{-1}\right.$ to $\left.450 \mathrm{sec}^{-1}\right)$ at $20^{\circ} \mathrm{C}$ for all species studied. Viscosity was also measured for rabbit blood at $37^{\circ} \mathrm{C}$ and chicken blood at $39^{\circ} \mathrm{C}$. In addition, the viscosity of pooled salmon blood was determined at $5^{\circ} \mathrm{C}$, the temperature of the ambient water in which these animals were caught.

The blood remaining after determination of hematocrit and viscosity was centrifuged for 5-10 minutes to separate RBCs from plasma. Autologous plasma was then recombined in various proportions with erythrocytes to obtain blood samples of different hematocrit ratios. Blood viscosity and hematocrit were measured for each aliquot as described above. Plasma viscosity was also determined for each species at the temperatures used in this study.

\section{Hemoglobin and Plasma Protein}


Hemoglobin concentration of whole blood and recombined blood was determined by the cyanmethemoglobin method using Sigma bovine hemoglobin standards.

Total plasma protein was determined by the Biuret reaction using Sigma protein standard solutions (Gornall et al., 1949).

\section{$\underline{\text { Statistics }}$}

Values are presented as mean \pm standard error of the mean. Exponential equations of the form: $y=a e^{b x}$ were $10 g$ transformed (i.e., lny $=\ln a+b x)$ so that standard least squares linear regression techniques could be used to obtain equations for those data. Slope and elevation comparisons were made between the various linear equations using Analysis of Covariance (Zar, 1980).

\section{RESULTS}

The hematological and rheological data for whole blood and plasma obtained in this study are summarized in Table I.

The relationship between viscosity and hematocrit was exponential and may be described by the general equation relating these variables:

$$
n_{b 1}=n_{p 1} e^{k H}
$$

where $n_{b l}$ is the viscosity of whole blood, $n_{p} 1$ is plasma viscosity, e is the natural logarithm base, $k$ is a constant and $H$ is the hematocrit. The curvilinear nature of this relationship for each species is shown in Figure 1 . 
Equation 1 may be linearized (see Methods) to obtain logarithmically transformed linear equations determined at a shear rate of $450 \mathrm{sec}^{-1}$ (Table II). There were significant $(P<.001)$ increases in the $y$-intercept value with decreasing temperature for those species whose blood viscosity was determined at more than one temperature; that is, chicken $(F 1,19=140.7)$, rabbit $(F 1,46=404.4)$ and salmon $(F 1,19=$ 273.9). There were no significant differences in the slopes of the lines equating viscosity and hematocrit for salmon $(s 1$ opes $=0.027,0.029 ; F 1,19=1.9)$ and rabbit $(s 1$ opes $=0.029,0.030 ; F 1,46=0.4)$ at either temperature (ANCOVA, P>.05). However, there was a significant $(\mathrm{P}<.01)$ increase in the slope of the regression line at $39^{\circ} \mathrm{C}(0.039 \pm$ $.002)$ compared to $20^{\circ} \mathrm{C}(0.034 \pm .001)$ for chicken blood $(F 1,53=8.66)$.

The influence of temperature on the viscosity of blood of salmon, chicken and rabbit was determined over a $5^{\circ}-39^{\circ} \mathrm{C}$ range (Figure 2 ). Viscosity at $40 \%$ hematocrit declined an average of $60 \%$ over the entire temperature range while plasma viscosity declined approximately $30 \%$ over the same interval.

Casson plots (Merrill, 1969) for whole blood at a hematocrit of $40 \%$ were constructed for each species used in this study (Figure 3 ). Plotting the square root of shear stress $\left(\zeta^{1 / 2}\right)$ as a function of the square root of shear rate $\left(\mathrm{y}^{1 / 2}\right)$ should yield a straight line with a slope of $\eta 1 / 2$ at shear rates higher than about $100 \mathrm{sec}^{-1}$. The plots were constructed by first determining the best fit linear relationship between shear stress $(\zeta)$ and hematocrit, then calculating particular values of $\zeta 1 / 2( \pm 2$ s.e. $)$ at each value of $v^{1 / 2}$. In this manner, each 


\section{TABLE I}

Values for Hematocrit (Hct; \%), Hemoglobin concentration (Hb; $g \%$ ), Mean Cell Hemoglobin Concentration (MCHC; $8 \%$ ), Blood viscosity ( $\eta_{b l} ; \mathrm{cP}$ ), Plasma viscosity $(n p l ; c P)$ and total protein $(g \%)$ for each of the species used in this study. Values are mean \pm S.E., with sample size (N). 


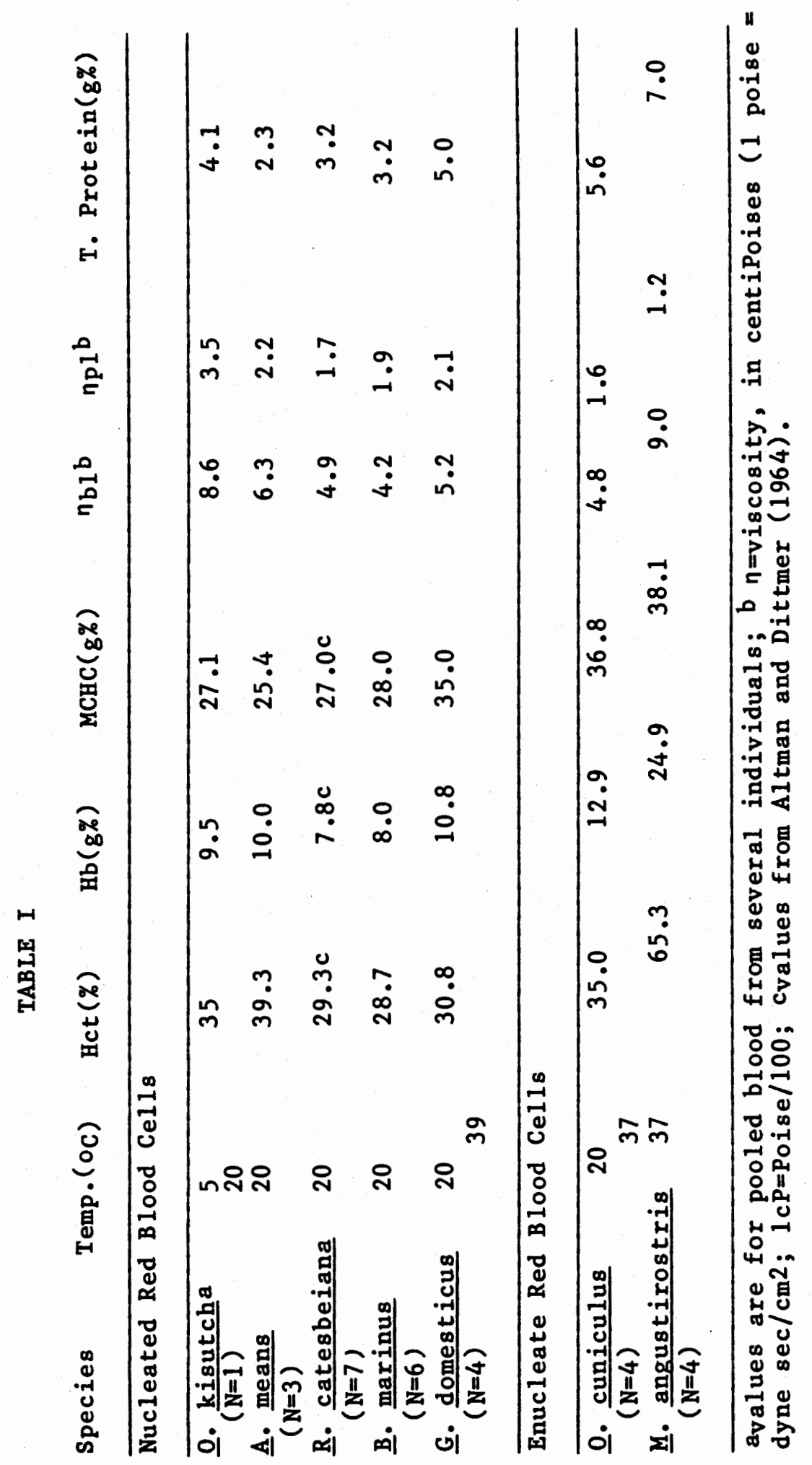




\section{TABLE II}

Slopes ( \pm 2 S.E.) and intercepts $( \pm 2$ S.E.) for the log-transformed relationship between viscosity and hematocrit determined at a shear rate of $450 \mathrm{sec}^{-1}$ for the species examined in this study. 


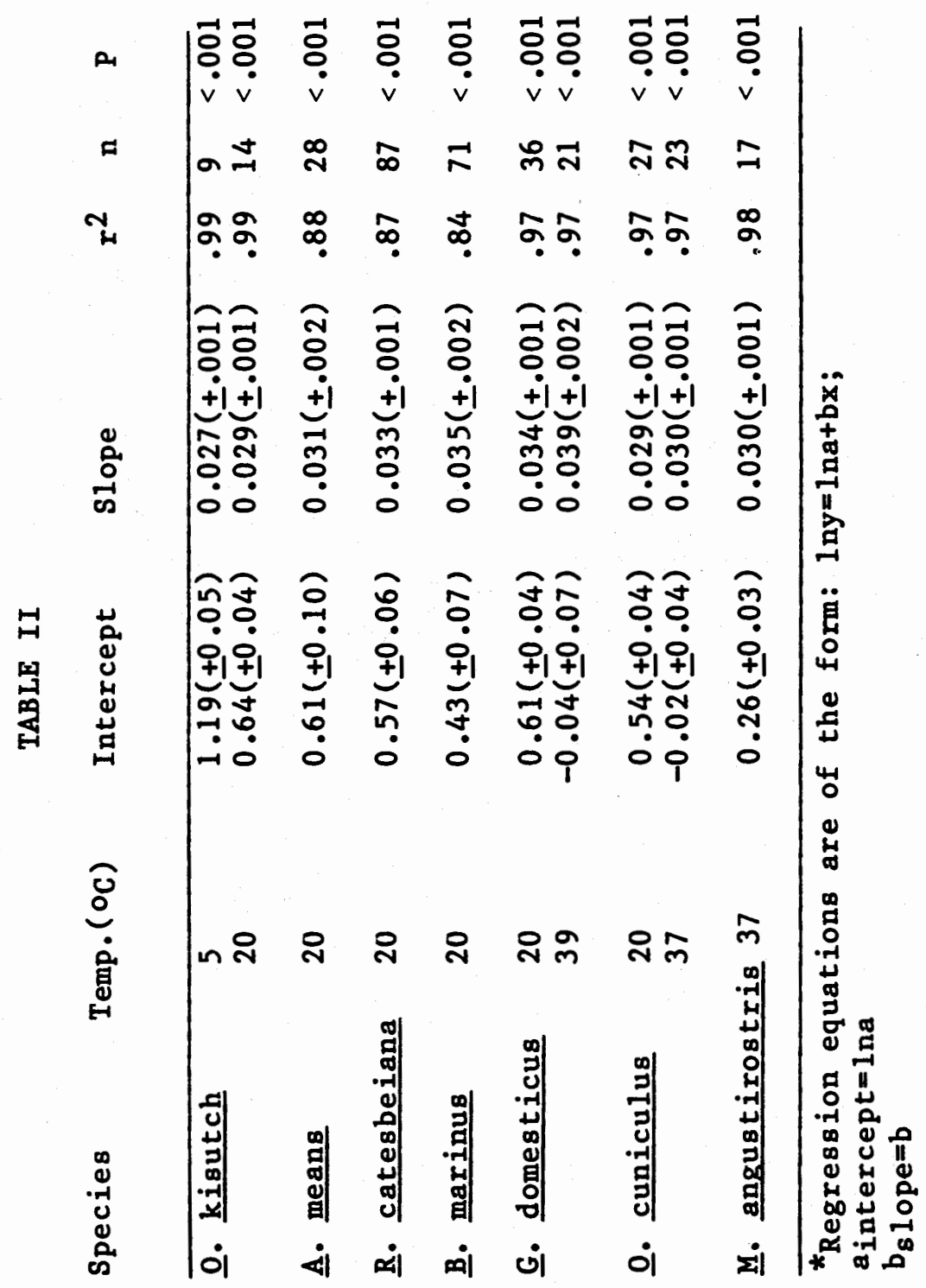


Figure 1.

Viscosity (centiPoise; CP) as a function of hematocrit ( $\%$ cells) for the species examined in this study. Viscosity measurements were determined at a shear rate of $450 \mathrm{sec}^{-1}$. Curvilinear regression lines were determined from the equations in Table II.

A. Salmon blood at $20^{\circ} \mathrm{C}(0 ; n=14)$ and $5^{\circ} \mathrm{C}(0 ; n=9)$.

B. Amphiuma blood at $20^{\circ} \mathrm{C} \quad(n=28)$.

C. Bullfrog blood at $20^{\circ} \mathrm{C} \quad(n=87)$.

D. Toad blood at $20^{\circ} \mathrm{C} \quad(n=71)$.

E. Chicken blood at $20^{\circ} \mathrm{C}(0 ; n=36)$ and $39^{\circ} \mathrm{C}(0 ; n=23)$.

F. Rabbit blood at $20 \mathrm{C}(0 ; n=27)$ and $37^{\circ} \mathrm{C}(0 ; n=23)$.

G. Elephant seal blood at $37^{\circ} \mathrm{C} \quad(n=17)$.

H. Salmon $\left(5^{\circ} \mathrm{C}\right.$ and $\left.20^{\circ} \mathrm{C} ; \Delta\right)$, chicken $(0)$, toad $(\square)$, amphiuma $(\Delta)$, bullfrog $(\square)$, and rabbit $(\bullet)$.

I. Chicken $(0)$, elephant seal $(\Delta)$ and rabbit $(0)$. 

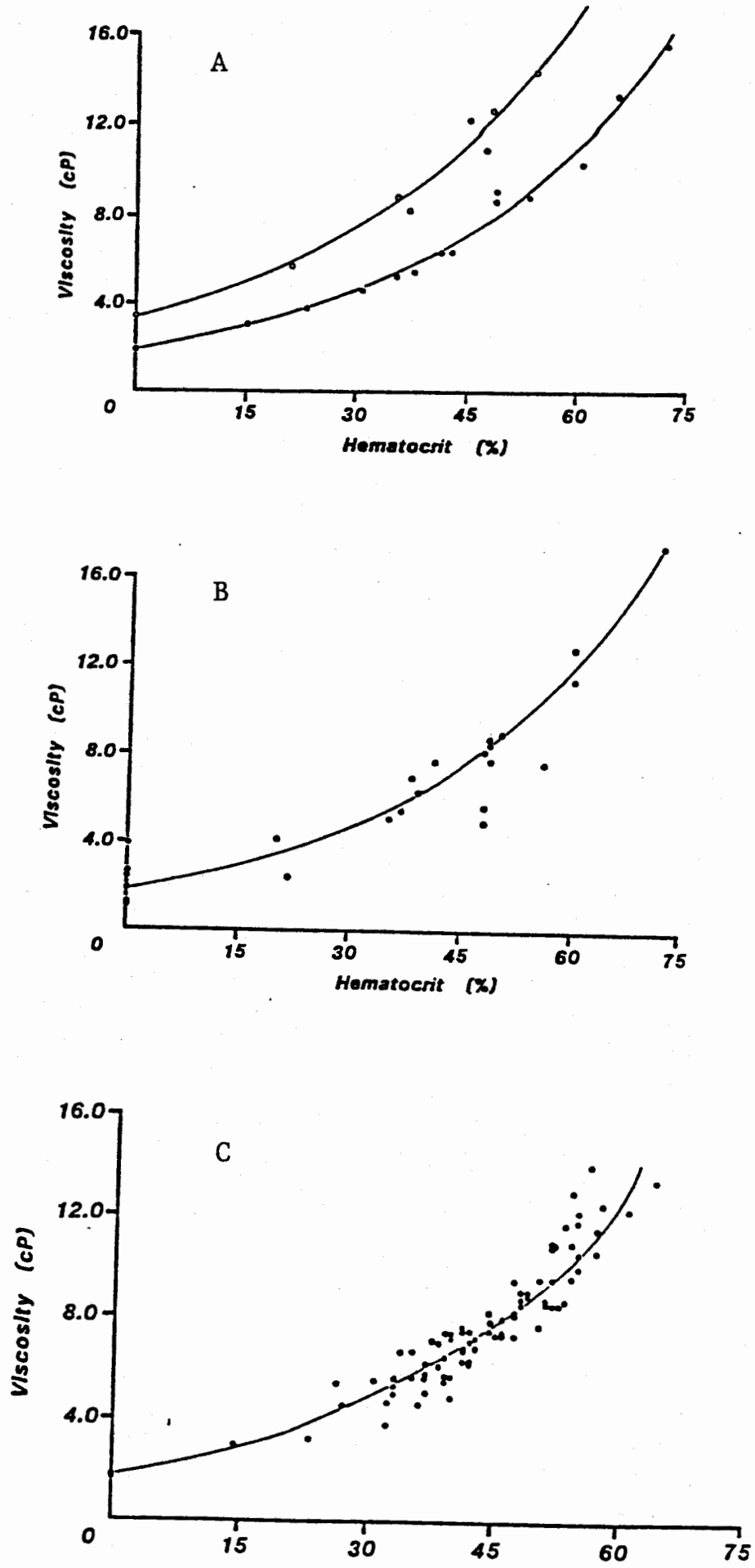

Hematocrit (\%) 

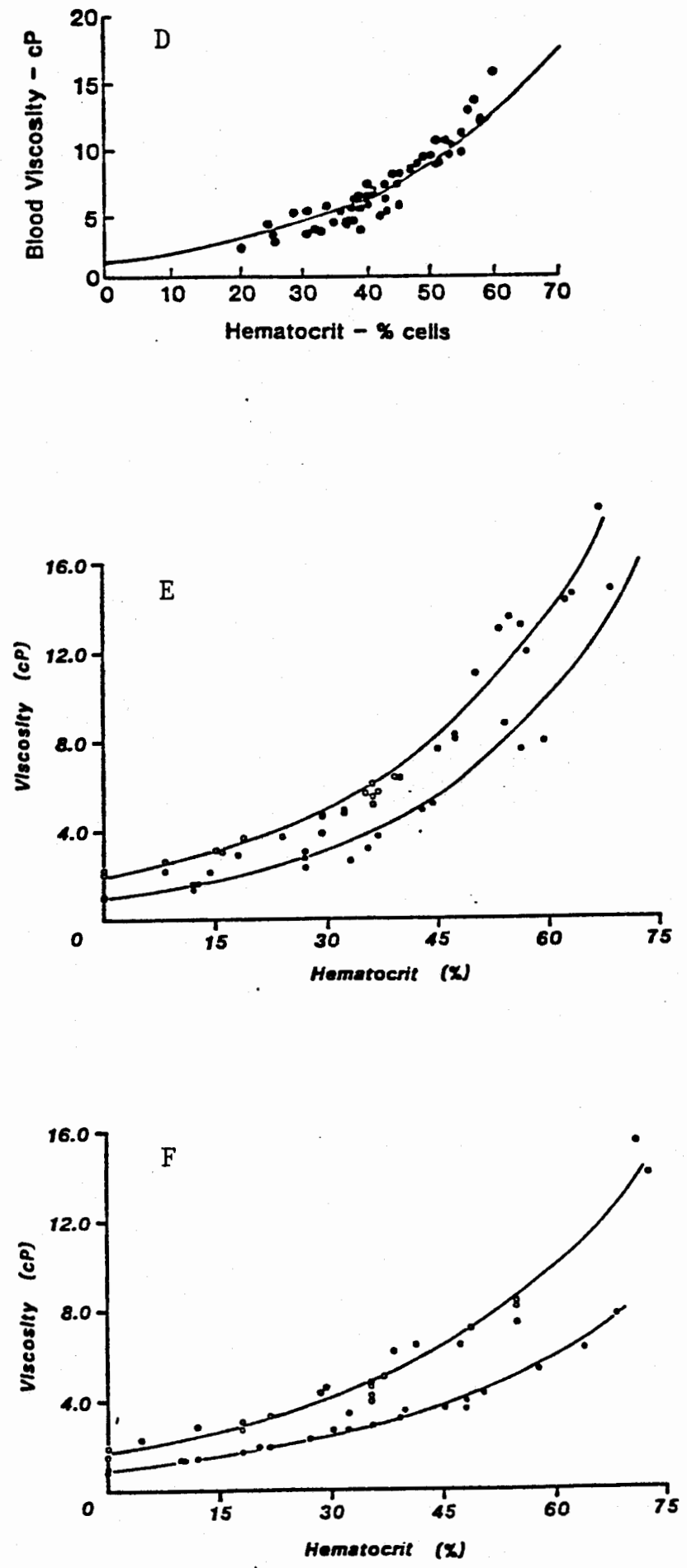

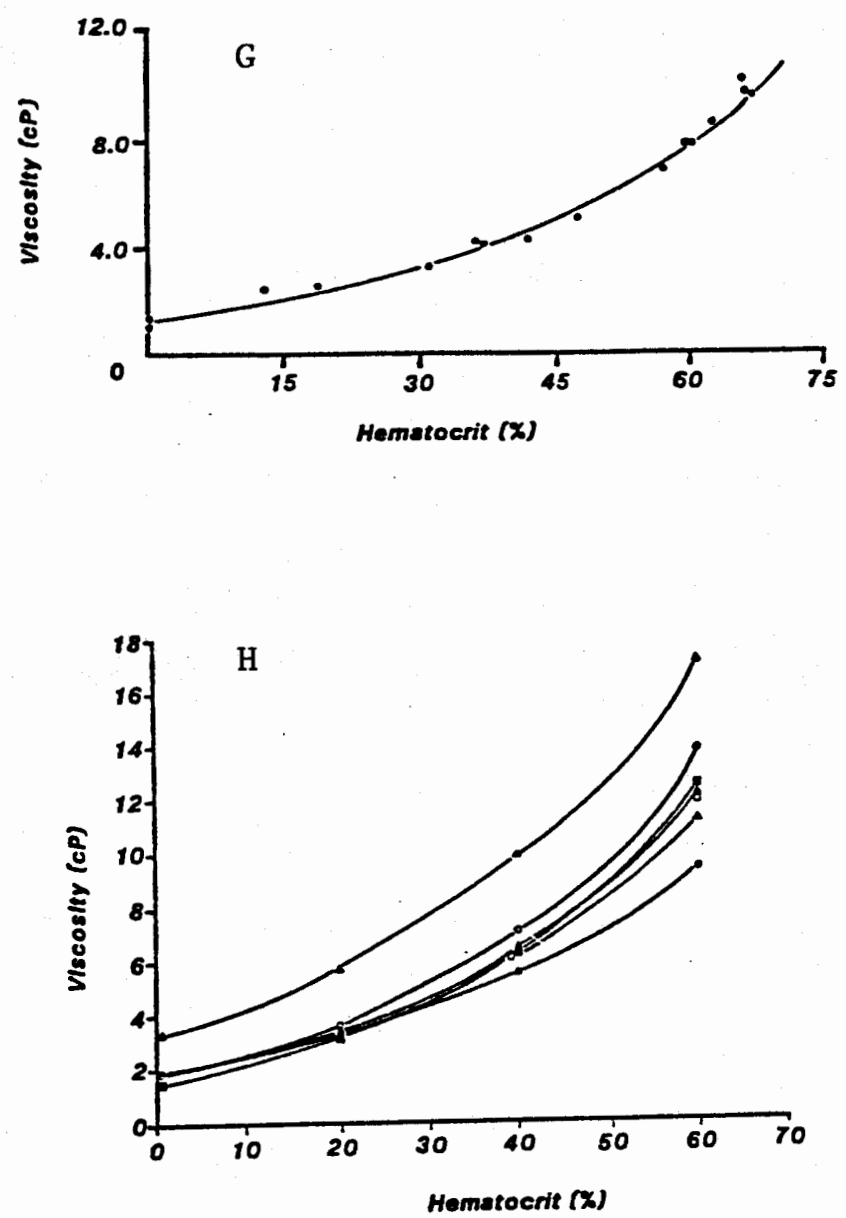


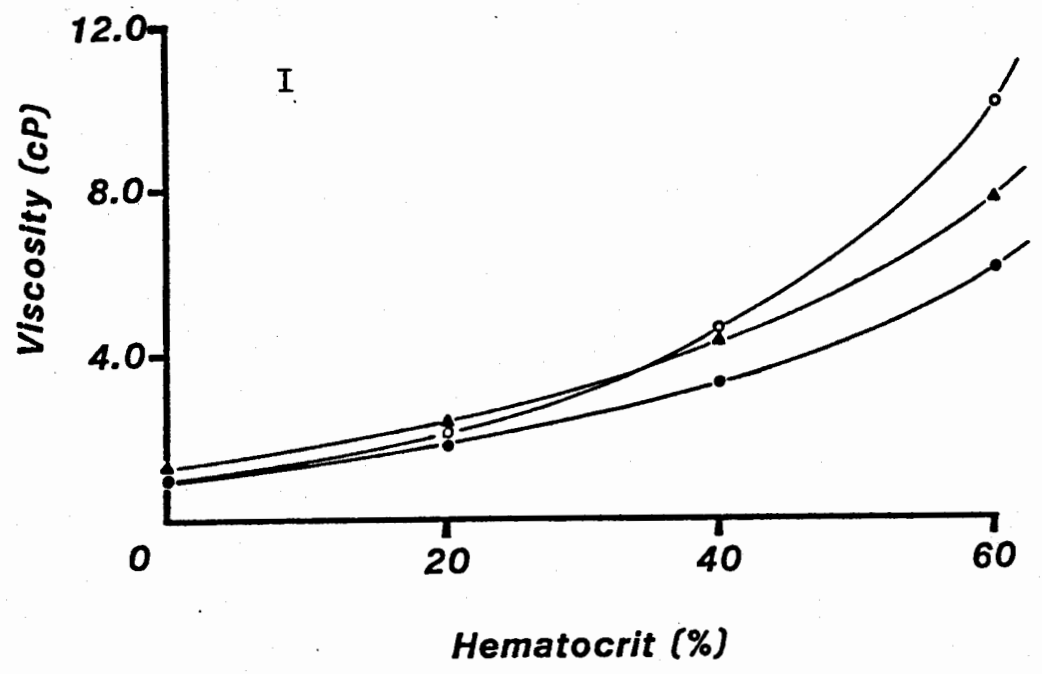


Figure 2 .

Viscosity (centiPoise; $c P$ ) as a function of temperature $\left({ }^{\circ} \mathrm{C}\right.$ ) for salmon ( $\Delta)$, rabbit $(O)$ and chicken (O) blood. Numbers indicate the hematocrit at which the measurements were taken. Shear rate was 450 $\sec ^{-1}$. 


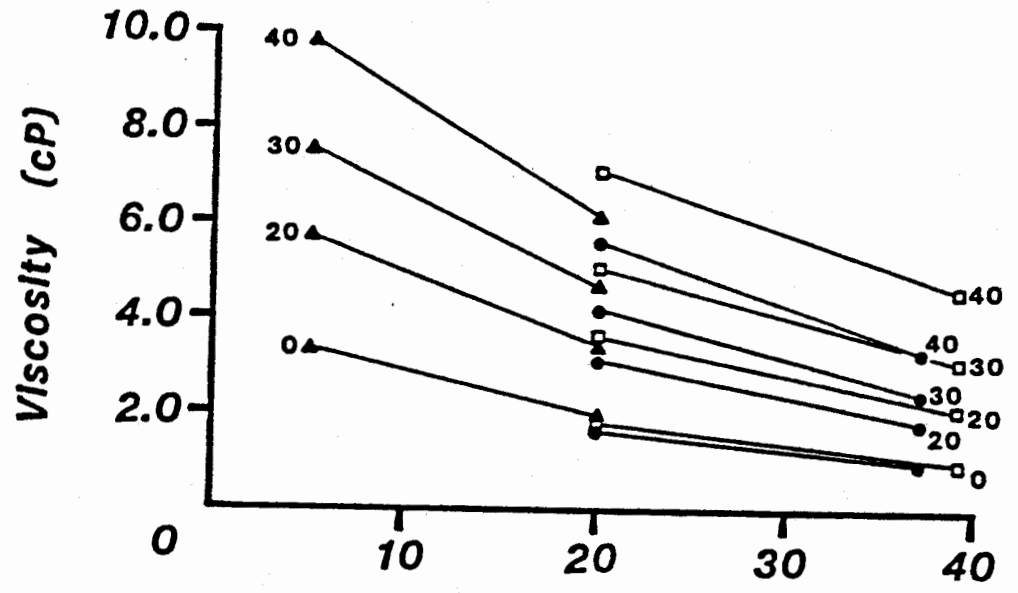

Temperature ${ }^{\circ} \mathrm{C}$ 
Figure 3 .

Square root of shear stress $\left(5^{1 / 2}\right)$ as a function of the square root of shear rate $\left(v^{1 / 2}\right)$. Mean values $( \pm 2$ S.E.) were determined at a hematocrit of $40 \%$.

A. Blood from rabbit $(0)$, chicken $(0)$, amphiuma $(\Delta)$, salmon $(\nabla)$, bullfrog $(\square)$ and toad $(\square)$ measured at $20^{\circ} \mathrm{C}$.

B. Blood from rabbit $\left(37^{\circ} \mathrm{C} ; 0\right)$, chicken $\left(59^{\circ} \mathrm{C} ; 0\right)$ and elephant seal $\left(37^{\circ} \mathrm{C}\right)$. 

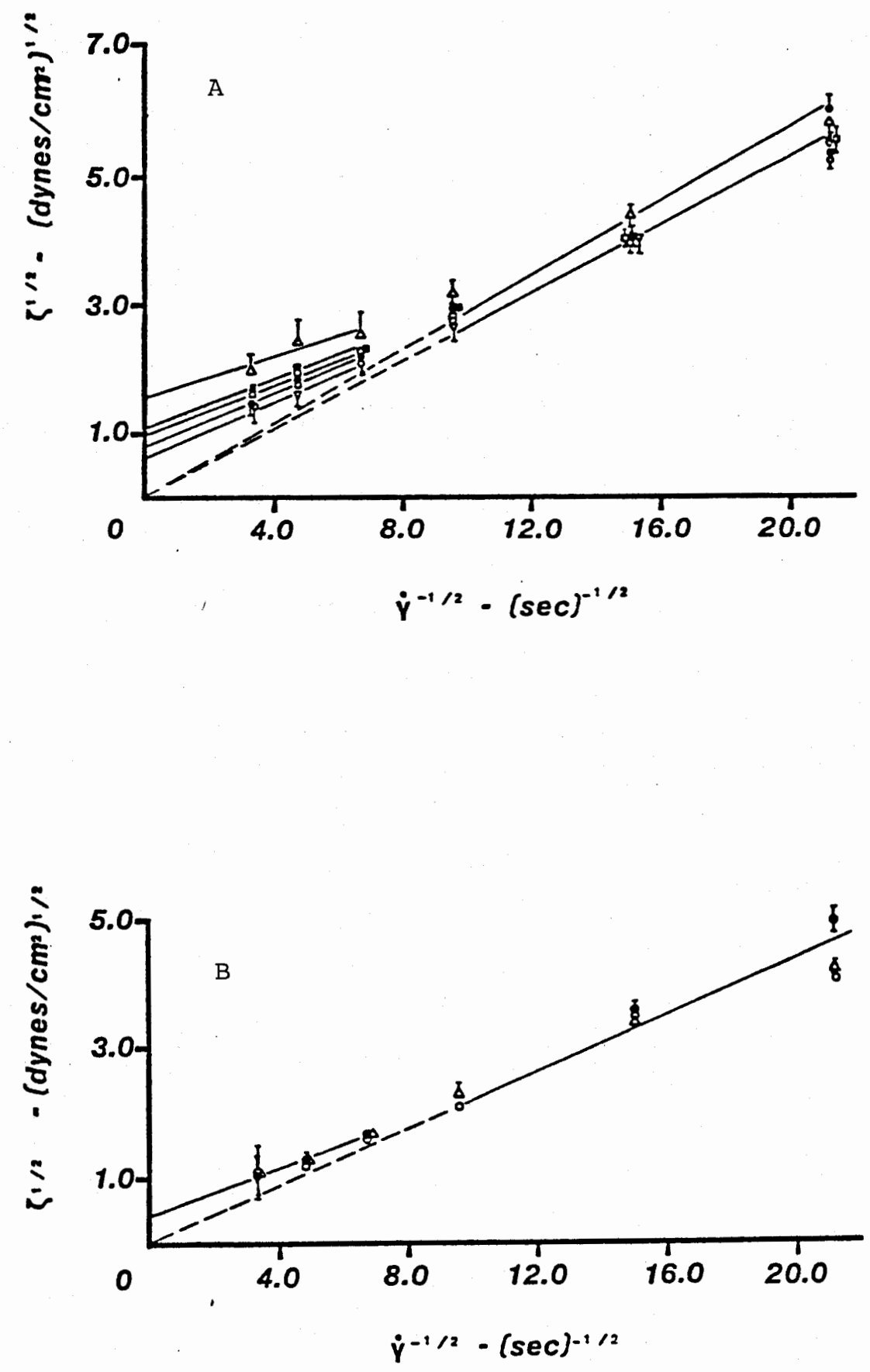
species can be compared at any specific hematocrit. One value of the Casson plot is that the $y$-intercept, or yield stress $\left(\zeta_{y}^{1 / 2}\right)$ may be calculated. Yield stress is the value of $\zeta$ at which blood will begin to flow under continued shear stress. Yield stress is a consequence of the anomalous non-Newtonian behavior of $\mathrm{RBC}_{8}$ in plasma (Merrill et al., 1963).

Osing the species data for BOC and blood viscosity, relative OTC in vitro was determined for each species at the temperatures used in this study (Figure 4). The dependent variable, OTC, was calculated as the product of $\mathrm{BOC}$ and $\mathrm{Qb1}$; the latter variable is described by the Po1seuille-Hagen flow equation:

$$
Q b 1=\Delta P n r^{4} / 8 n L
$$

BOC was calculated as the product of $(\mathrm{Hb})$ and the oxygen binding capacity of $(\mathrm{Hb})$, which is typically about $1.3 \mathrm{ml} 02$ per gram of hemoglobin:

$$
\mathrm{BOC}=1.3(\mathrm{Hb})
$$

Since Qbl is inversely related to blood viscosity by (2), then:

$$
\mathrm{Qbl} \propto 1 / \mathrm{n} b 1
$$

Combining equations 1,3 and 4 , OTC becomes:

$$
\operatorname{OTC} \propto 1.3(\mathrm{Hb}) / \mathrm{npl} \mathrm{e}^{\mathrm{kH}}
$$


The exponential increase in blood viscosity with hematocrit for those species investigated here (Figure 1) was typical of vertebrate blood, and similar to that reported for fish (Graham and Fletcher, 1983), amphibians (Ch1en et al., 1971; Weathers, 1976a), birds (Usami et al., 1970; Viscor et al., 1984) and mamma1s (Stone et al., 1968; Guard and Murrish, 1975; Snyder and Weathers, 1977). The exponential nature of the viscosity-hematocrit relationship is important since flow is inversely proportional to blood viscosity, and blood flow -is potentially limiting to OTC. Any factor that reduces blood viscosity may augment oxygen delivery to the tissues.

Viscosity of mammalian enucleate (rabbit) blood was lower than v1scosity for nucleated $\mathrm{RBC}$ at $20^{\circ} \mathrm{C}$, particularly at higher hematocrits (Figure 1H). The differences in blood viscosity must be attributed to differences in the RBCs since plasma viscosity was similar for all species (Table I). Usami et al. (1970) also reported that nucleated (turkey) RBCs were significantly more viscous than mammalıan RBCs at equivalent hematocrits. The decrease in viscosity of mammalian versus non-mammalıan blood is generally attributed to a greater deformability of enucleate RBCs compared to nucleated RBCs (Chien et al., 1971; Usami et al., 1970). The resulting reduction in viscosity of mammalian RBCs might be advantageous compared to nucleated cells in terms of enhancing OTC by increasing blood flow at equivalent hematocrits. Enucleate RBCs of rabbit and elephant seal also had a lower viscosity than nucleated (chicken) RBCs when measured at physiologically relevant temperatures (Figure 1I). It appears as though elephant seal blood is intermediate in viscosity compared to rabbit and chicken blood. Although the log 
transformed intercept value (Table II) corresponding to plasma viscosity is significantly greater for elephant seal blood (ANCOVA, P<.05), the actual plasma viscosities (Table I) were not significantly different (Student-Newman-Keuls test, P>.05). Nevertheless, it consistently appears that nucleated $\mathrm{RBCs}$ are more viscous at higher hematocrits. The normal high hematocrit (65\%) of elephant seal blood greatly increases BOC but the resulting increased viscosity may be actually deleterious with regard to oTC (see below).

Blood is a non-Newtonian fluid; that is, viscosity is shear dependent at low rates of shear. The Casson plot (Figure 3) allows one to readily determine the yield shear stress of blood by extrapolation to zero shear rate. Yield stress is a result of the viscoelastic nature of RBCs (Merrill et al., 1963). Although the significance of yield stress in vivo has yet to be determined, lower values of yield stress in some marine and arctic mammals have been interpreted as a means of maintaining peripheral blood flow in low temperature environments (Halikas, 1971; Guard and Murrish, 1975). Maclean (1981) reported a reduced shear rate dependence of viscosity for blood of hibernating ground squirrels and chipmunks, which would also serve to maintain flow when body temperature is low.

In this study only the yield shear stress of amphiuma $\mathrm{RBCs}$ at $20^{\circ} \mathrm{C}$ was different from the other yield stress values (Figure $3 A$ ). The increase in yield stress of amphiuma $\mathrm{RBCs}$ may reflect the significantly larger size of those nucleated cells compared to other nucleated and enucleate cells. Although RBC size per se is not a determining factor of blood viscosity, perhaps RBCs such as those of amphiuma have a 
significantly higher yield stress as a consequence of a very large cell size. The increased yield stress of amphiuma blood cannot be due to high plasma protein concentrations since these animals had the lowest concentrations compared to the other species examined here (Table I).

The influence of temperature on the viscosity of plasma and whole blood is significant. There is an approximately $60 \%$ reduction in blood viscosity over the $5-370^{\circ} \mathrm{C}$ range at a hematocrit of $40 \%$ (Figure 2 ). Langille and Crisp (1980) found a similar reduction (50\%) in viscosity of bullfrog blood over equivalent temperatures and hematocrits. The influence of temperature on blood viscosity is well known and is of particular relevance to ectothermic vertebrates (Snyder, 1971; Maclean et al., 1975). Those animals whose $\mathrm{Tb}$ is dependent upon the environmental temperature will be expected to have Tb-dependent changes in blood viscosity and, hence, blood flow (see Chapter 2).

Ectotherms are generally characterized by having lower, or variable, Tbs, and also have lower hematocrits and/or MCHCs (Chien et al., 1971; Table I). It would seem likely that ectotherms would incur fluctuations in blood flow due to the temperature dependence of blood viscosity, whereas endotherms with high and constant Tbs would not. Mammals and birds may, therefore, be able to attain high BOCs to sustain elevated rates of $\mathrm{V} 02$ without suffering reductions in blood flow due to viscosity except at high (i.e. > 45\%-50\%) hematocrits, when small increases in Hct cause large increases in viscosity. Blood at $37^{\circ} \mathrm{C}$ can have about $2 \mathrm{X}$ the hematocrit as blood at $5^{\circ} \mathrm{C}$, yet have the same viscosity. This is probably reflected in the normally higher (40-50\%) hematocrits seen in endotherms compared to ectotherms. 


\section{Optimal Hematocrit for Oxygen Transport}

Since Crowell and Smith (1967) postulated that the Ho for oxygen transport in glass tubes and biological systems are generally equivalent, it has been observed in a number of vertebrates that the observed hematocrit is in close correspondence with the predicted Ho determined in vitro (see Stone et a1., 1968; Snyder, 1971; Weather8, 1976a).

The results presented here indicate that most animals do have hematocrits normally at the optimum value (Table III). The plateau for maximum OTC is, however, relatively broad and covers a large range of the hematocrit ratio (Figure 4). Moreover, as temperature is reduced, the plateau for OTC becomes even wider.

Many ectotherms show reductions in hematocrit level when $\mathrm{Tb}$ is lowered (Snyder, 1971; Maclean et al., 1975; Weather8, 1976a), with the predicted Ho value exhibiting parallel reductions with temperature. These observations have led some workers to argue that reducing hematocrit with Tb is a means of conserving cardiac energy by lowering viscosity (Snyder, 1971; Weathers, 1976a). However, some endotherms show an opposite response to decreased $\mathrm{Tb}$; that is, hematocrit increases as a result of hemoconcentration due to splenic contraction and reduced plasma volume (Maclean, 1981).

Resting animals can presumably alter blood flow by changing peripheral resistance as circulatory conditions warrant, however, this may not always be the case (see Chapter 2). Any deviation from the Ho value may be readily compensated for by vasomotion in the peripheral 


\section{TABLE III}

Measurement of observed hematocrit (\%), predicted in vitro optimal hematocrit (Ho; \%), range of hematocrits for $95 \%$ of maximum oxygen transport capacity (OTC) and the percent deviation of observed Hct compared to the predicted Ho. 


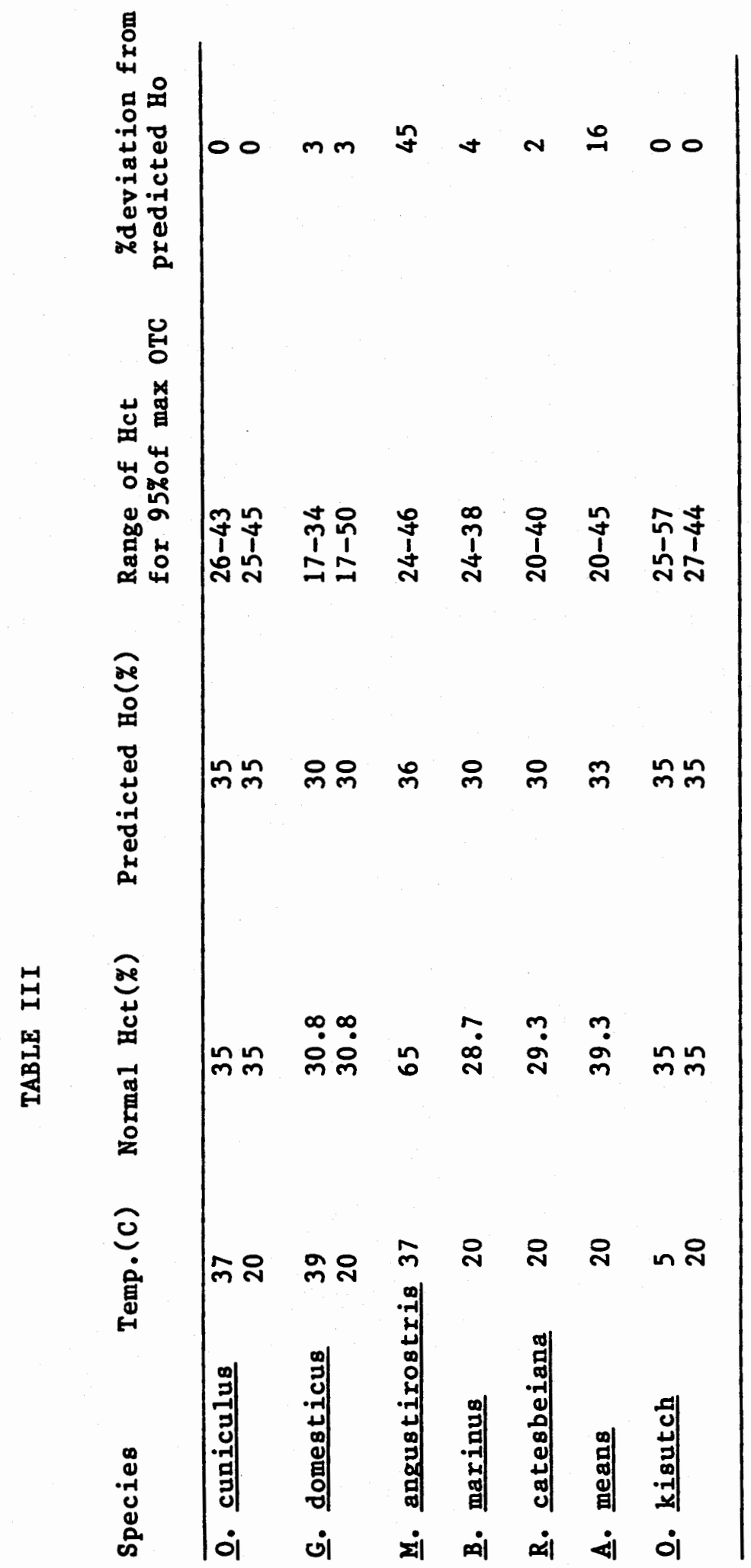


Figure 4.

Oxygen transport capacity in $\mathrm{ml} 02(100 \mathrm{ml} \mathrm{blood} \mathrm{cP})^{-1}$ as a function of hematocrit $(\%$ cells).

A. Blood from rabbit $(0)$, chicken $(\Delta), \operatorname{toad}(\Delta)$ at $20^{\circ} \mathrm{C}$ and salmon $\left(20^{\circ} \mathrm{C}, \mathrm{D} ; 5^{\circ} \mathrm{C}, \mathrm{Z}\right)$.

B. Blood from rabbit $\left(37^{\circ} \mathrm{C} ; \mathrm{O}\right)$, elephant 8 eal $\left(37^{\circ} \mathrm{C} ; O\right)$ and chicken $\left(39^{\circ} \mathrm{C} ; \Delta\right)$ 

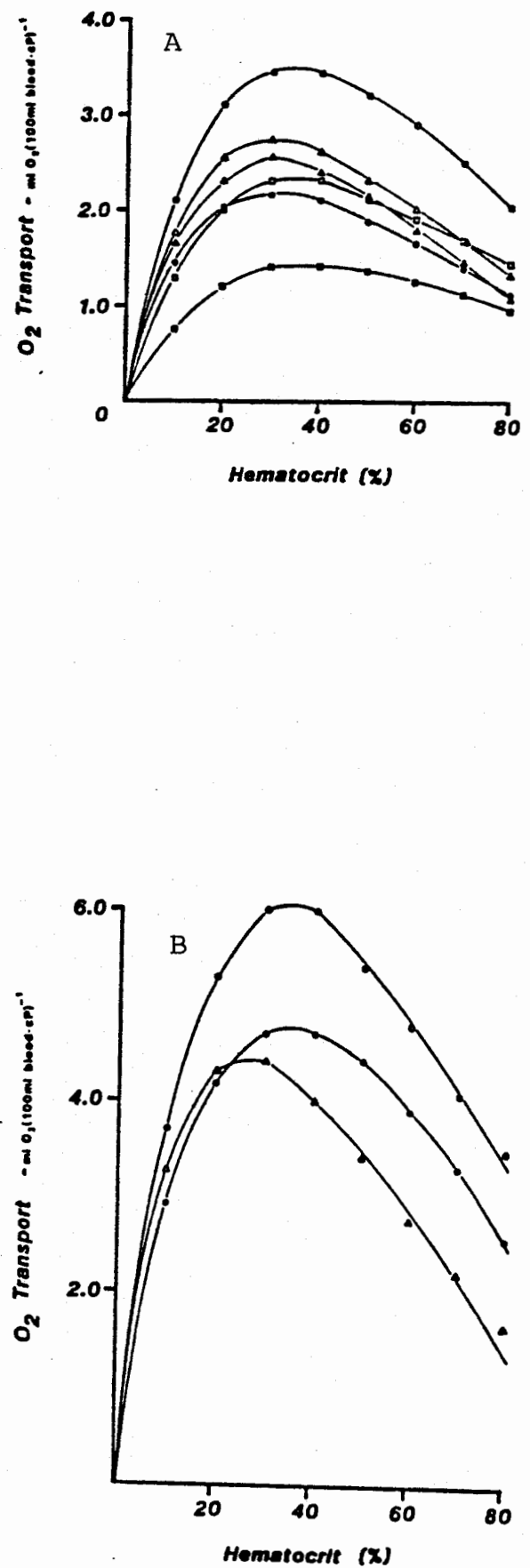
vasculature. Thus Ho theory may be more applicable in vivo during maximal oxygen consumption ( $\mathrm{V} 02, \max )$, when presumably there is less scope for further vasomotion adjustment of blood flow. Hillman et al. (1985) demonstrated that any increases beyond the normal, and optimal, hematocrit resulted in a reduction in blood flow and v02, max in Bufo marinus. They concluded that maximally excercised animals had no further capacity (i.e. decrease in peripheral resistance) for augmenting OTC due to an increased viscosity load.

The only animal that did not show a correlation between the predicted Ho and the observed hematocrit was the elephant seal (Figure 4B). The OTC corresponding to the normal hematocrit in this species (65\%) was $70 \%$ of the predicted maximum value. If Ho is more relevant to OTC during V02, max, then one would predict that elephant seals will have significantly lower values of maximal aerobic capacity.

Elephant seals are deep diving pinnipeds requiring large oxygen stores. The high hemoglobin and MCHC values are adaptive to its physiological ecology (Ridgway, 1972). Thus elephant seals may lose some ability to transport oxygen maximally, but the benefits of increasing oxygen stores for diving may far outweigh the need to maximize the rate of oxygen transport. 
CHAPTER II

THE EFFECTS OF TEMPERATURE AND ACTIVITY ON HEART RATE, BLOOD FLOW RATE AND BLOOD VISCOSITY IN BUFO MARINUS

\section{INTRODUCTION}

The cardiovascular adjustments of amphibians to changes in body temperature ( $\mathrm{Tb}$ ) or activity have been well studied (Hillman, 1976; Weathers, 1975,1976b; Seymour, 1973; Carey, 1979; Taigen et al., 1982). Increased rates of oxygen consumption (V02) are the result of increases in cardiac output (heart rate $X$ stroke volume) and arteriovenous (A- $\nabla$ ) difference in blood 02 content, or a combination of these parameters. However, the relative contributions of each are difficult to assess in amphibians. It is as yet unclear in amphibians to what degree $\nabla 02$ is augmented by cardiac output and $A-\nabla$ difference with changing $T b$ and activity.

Although there have been relatively few measurements of in vivo blood flow rates in the circulatory systems of anuran amphibians, previous work has focused primarily on cardiovascular adjustments to temperature acclimation in resting animals (Weathers, 1975, 1976b). There are few data available for in vivo circulatory responses to acute exposure to temperature, or during maximal rates of oxygen consumption ( $(\nabla 02, \max )$ (Withers et al., 1984). 
It is not known to what extent blood viscosity affects blood flow rates of ectotherms in vivo. As described in the previous chapter, blood flow and blood viscosity are inversely related, and each is dependent upon temperature. Passive changes in blood viscosity as the result of $\mathrm{Tb}$ fluctuations in amphibians should be reflected to some degree in blood flow changes measured in vivo. Langille and Crisp (1980) suggested that ectotherms exposed to large fluctuations in environmental temperature will experience proportionally large changes in blood viscosity thereby affecting blood flow rates and heating and cooling of animals.

The purpose of this investigation is to further elucidate the relative contributions of heart rate and stroke volume in an anuran amphibian (Bufo marinus) to increased blood flow rates and metabolic demands with increased $\mathrm{Tb}$ and during activity. The role of blood viscosity measured in vitro is also assessed in relation to blood flow adjustments observed in vivo with adjustments to changing $\mathrm{Tb}$ during rest and activity.

\section{MATERIALS AND METHODS}

\section{Anima18}

Bufo marinus $(175-375 \mathrm{~g}, \quad \mathrm{x}=275 \mathrm{~g})$ were purchased from commercial suppliers and maintained in the laboratory at $20 \mathrm{C}$ with water available. Photoperiod was not controlled.

\section{Blood Flow Rates}


The animals were anaesthetized by immersion in a solution of Tricainemethanesulfonate (MS 222, Sigma Chemicals). The toads were placed dorsal side up and a midlateral incision was made immediately posterior to the parotid gland to isolate the paired systemic arches. A 2.0 or $2.5 \mathrm{~mm}$ (internal diameter) magnetic blood flow probe (In Vivo Metrics, Healdsburg, CA) was placed around both systemic arches anterior to the dorsal aorta. The probe was secured to the dorsal body wall and the skin and musculature incisions were separately sutured closed. The toads were allowed 1 to 2 days to recover from the surgery and to allow time for the flow probe output signal to stabilize. The dc output of the probe was amplified $1000 X$ with a dc preamplifier and recorded on a Narco-Bio Systems Physiograph. Probes were calibrated as previously described (Hillman et a‥, 1985).

Resting rates of blood flow were determined by maintaining toads in a dark container for 1 to 3 hours and intermittently recording blood flow. The lowest values obtained were taken as resting blood flow rates. Heart rate was calculated from the time course of the blood flow trace. Average pulse volumes were determined by integrating the area under the blood flow curves.

Maximal rates of blood flow for the toads were elicited by exploiting a behavioral righting response characteristic of anurans. Th1s procedure has previously been described elsewhere as a method for determining V02max in amphibians (Seymour, 1973; Hillman et a1., 1979). Briefly, the procedure consisted of repeatedly flipping the animal on its back for 3 minutes, a period of time previously found long enough 
to elicit V02max (Hillman, 1976). Blood flow rate was recorded for approximately 30 seconds immediately following the exercise bout.

\section{Blood Flow Rates at Low and High Temperatures}

The effect of low $\left(10^{\circ} \mathrm{C}\right)$ and high $\left(30^{\circ} \mathrm{C}\right)$ body temperatures $(\mathrm{Tb})$ on blood flow rates were determined for resting and active toads. The procedure consisted of placing individual toads in plastic containers (29 $\mathrm{cm}$ long $\times 18 \mathrm{~cm}$ wide $\mathrm{X} 13 \mathrm{~cm}$ deep) and immersing the container inside a Forma Scientific (Model 2095) constant temperature circulating water bath regulated to $\pm 0.5^{\circ} \mathrm{C}$. The container with the toad was anchored in the water so the level of circulating water was approximately $5 \mathrm{~cm}$ from the top of the container. A lid was placed over the entire apparatus leaving a small space for blood flow and temperature thermocouple leads to exit to recording equipment. Tb of the body and ambient temperature inside the water bath air space were continuously monitored with a Bailey Bat -4 thermometer to $\pm 1.0^{\circ} \mathrm{C}$. During the $10^{\circ} \mathrm{C}$ and $30^{\circ} \mathrm{C}$ temperature regimes, resting blood flow rates were recorded as above when the animals had achieved the lowest heart rates after $\mathrm{Tb}$ had become stable. Maximal blood flow rates at $10^{\circ} \mathrm{C}$ and $30^{\circ} \mathrm{C}$ were determined by the flipping technique described above when the animals had reached a stable Tb.

\section{Standard and Active Metabolic Rates}

Standard and active rates of metabolism were determined for toads at all three body temperatures. All rates were determined by the closed respirometry method described in detail elsewhere (Billman, 1976). Briefly, the procedure for determining v02 for resting animals consisted 
of placing them in individually sealed metabolic chambers ( $3875 \mathrm{ml})$ in the dark for 1-4 hours, depending on the temperature regime used. After an appropriate time interval, a $50 \mathrm{ml}$ sample of air was withdrawn from the chamber and injected into a Beckman OM-14 oxygen analyzer through a column of drierite and ascarite to remove water and carbon dioxide, respectively. Resting rates of $\nabla 02$ were determined using the equations of Seymour (1973). The $10^{\circ} \mathrm{C}$ and $30^{\circ} \mathrm{C}$ standard metabolic rates were determined for toads in sealed metabolic chambers placed inside a constant cabinet. The toads were kept inside the chamber for about 2 hours to allow $\mathrm{Tb}$ equlibration with ambient air. The animals were then sealed in the metabolic chambers, an air sample withdrawn and analyzed for 02 content as described.

\section{Blood Viscosity}

Viscosity was determined for blood of three toads (hematocrit range 20-25\%) at the Tb's used in this study, as described in the previous chapter.

\section{Statistics}

Values are presented as mean \pm standard error of the mean. Paired t-tests were used to determine significant differencs between means. The Student-Newman-Keuls analysis of variance was used to determine differences between three or more means (Zar, 1980). The level of significance was taken as $\mathrm{P}<.05$

\section{RESULTS}

Heart Rate, Systemic Arch Pulse Volume and Blood Flow Rates 
Mean values of standard and active heart rates, systemic arch pulse volumes and blood flow rates at the three temperatures used in this study are given in Table IV. There were significant $(P<.05$, paired $\mathrm{t}$-test) increases in heart rate with activity at each $\mathrm{Tb}$ examined. Heart rate also increased significantly (Student-Neuman-Keuls test, $P<.05)$ with temperature during rest, and with activity (Table IV, Figure 5).

Systemic arch pulse volume (SAPV) generally decreased with increased activity and heart rate (Figures $7-9$ ), but there was no significant overall reduction $(P>.05)$. However, there was a significant reduction in SAPV with activity for animals at $10^{\circ} \mathrm{C}$ when examined on an individual basis as a per cent change from resting values. There were also significant reductions in pulse volume between $10^{\circ} \mathrm{C}$ and $30^{\circ} \mathrm{C}$, and during rest and activity (Table IV).

There were significant increases in mass-specific rates of blood flow with activity at $20^{\circ} \mathrm{C}$ and $30^{\circ} \mathrm{C}$, but not at $10^{\circ} \mathrm{C}$ (Table IV; Figure 10). Blood flow rates also increased significantly with temperature during rest and during activity except for resting toads in the $10^{\circ} \mathrm{C}-$ $20^{\circ} \mathrm{C}$ interval.

\section{Metabolic Rates}

Standard and active rates of metabolism at $10^{\circ} \mathrm{C}, 20^{\circ} \mathrm{C}$ and $30^{\circ} \mathrm{C}$ are given in Table $\nabla$. The Q10 values for the temperature intervals used are also indicated. There was a significant $(P<.001)$ increase in V02 with activity, at all temperatures. The increase in V02 with activity is reflected by a $5.5 \mathrm{X}, 8.9 \mathrm{X}$ and $11.8 \mathrm{X}$ elevation in factorial scope at $10^{\circ} \mathrm{C}, 20^{\circ} \mathrm{C}$ and $30^{\circ} \mathrm{C}$, respectively. 
TABLE IV

Cardiovascular variables measured for Bufo marinus. Values are mean \pm S.E. Number of observations $(N)$ is also given. 


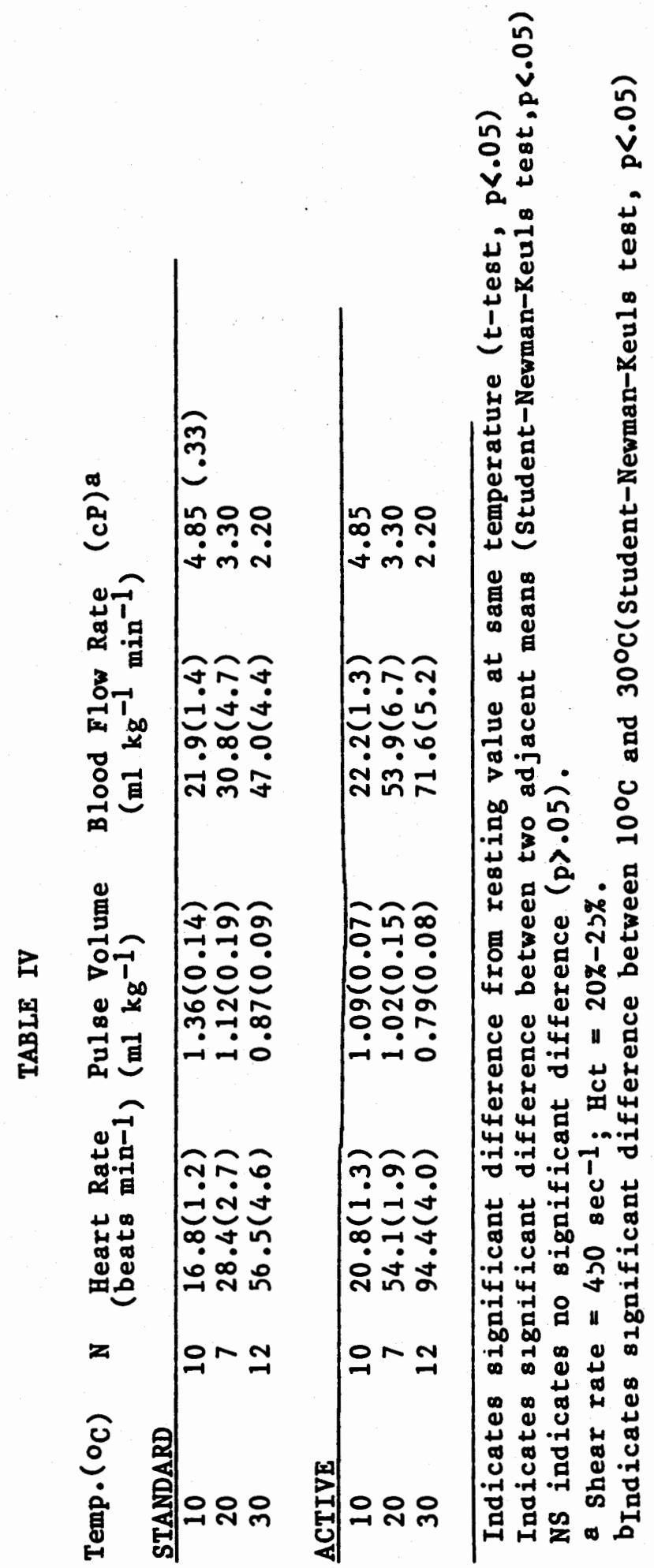




\section{Figure 5.}

Heart rate (beats $\mathrm{min}^{-1}$ ) as a function of temperature ( ${ }^{\circ} \mathrm{C}$ ) for Bufo marinus at rest (closed circles) and during activity (open circles). Values are mean \pm 2 S.E. 


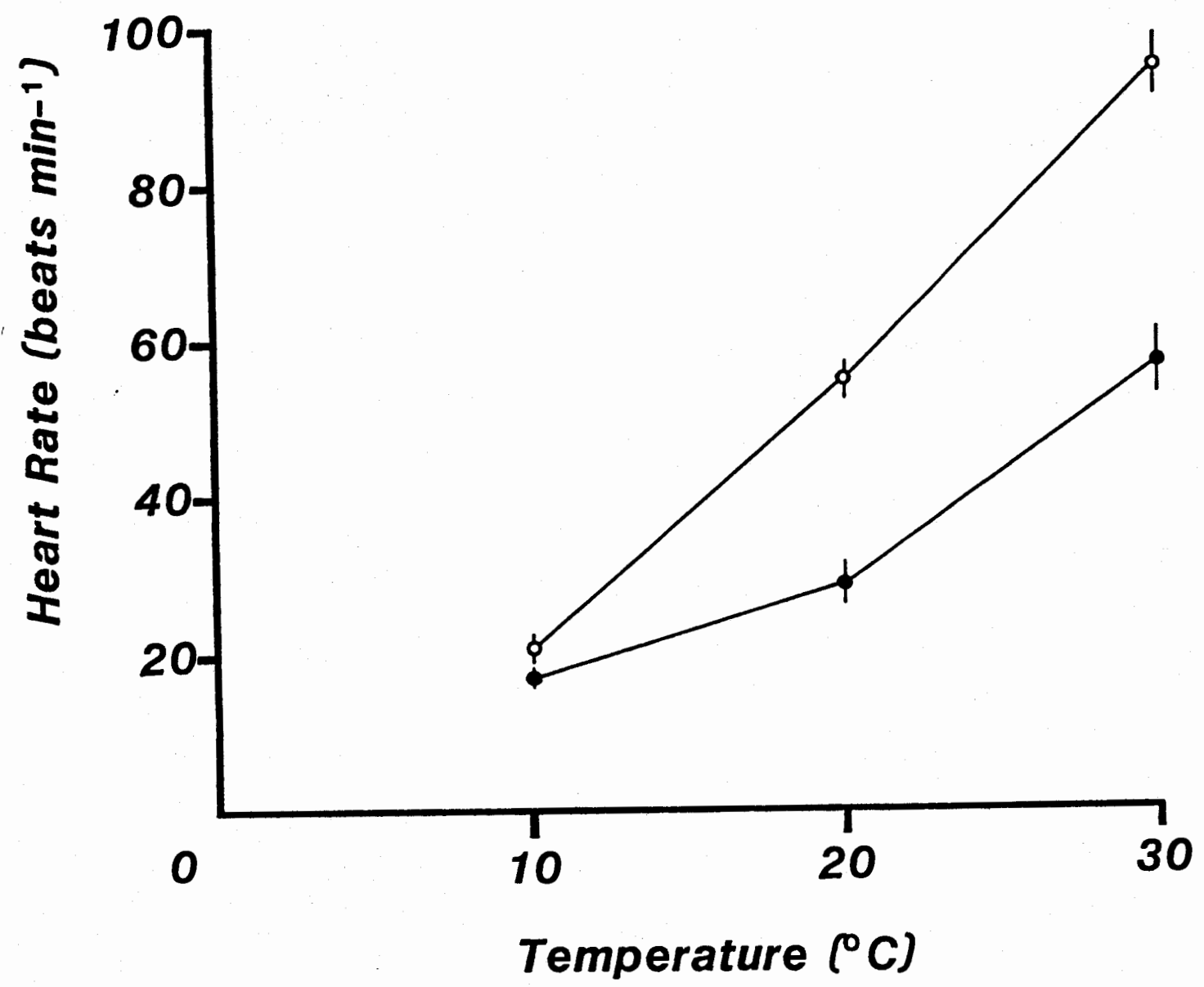




\section{TABLE V}

Metabolic rates (V02; $\mathrm{ml} 02 \mathrm{~g}^{-1} \mathrm{~h}^{-1}$ ) of resting and active toads. Values are mean \pm S.E. and number of observations (N). The absolute metabolic scope (active-resting), factorial scope (active/resting) and Q10 values are also given. 


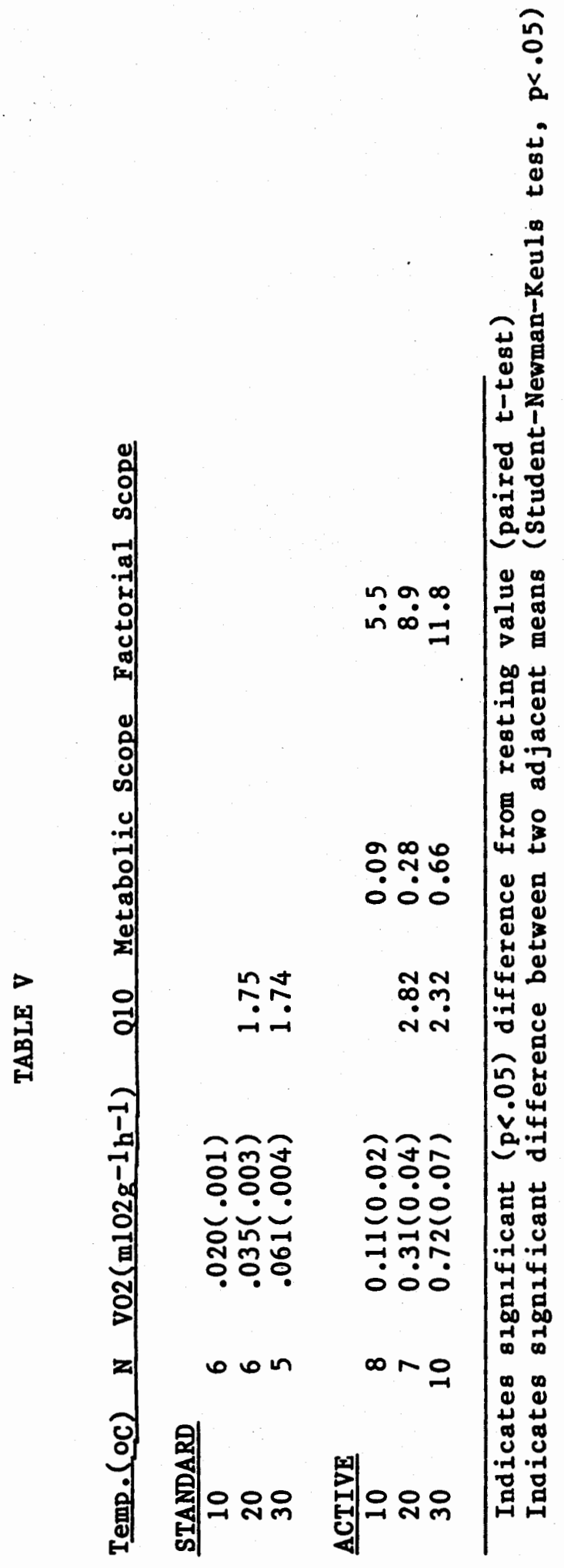




\section{Figure 6 .}

Log $v 02\left(\mathrm{ml} 02 \mathrm{~g}^{-1} \mathrm{~h}^{-1}\right)$ as a function of temperature $\left({ }^{\circ} \mathrm{C}\right)$ for $\underline{B}$. marinus at rest (closed circles) and during activity (open circles). Mean values \pm 2 S.E. are also indicated. 


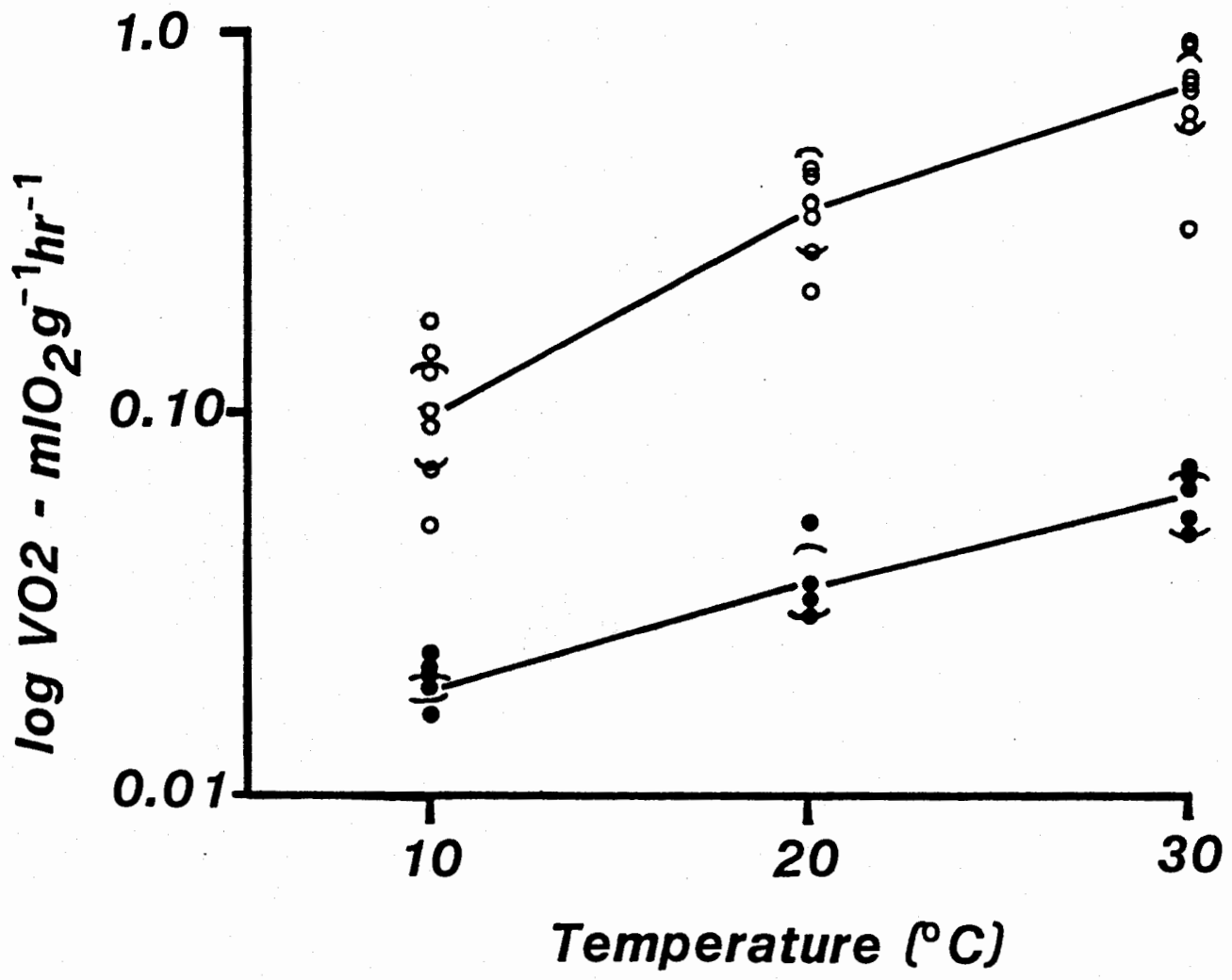


There was a positive influence of $\mathrm{Tb}$ on standard and active rates of metabolism (Table V). Figure 6 shows the relationship between $\nabla 02$ (log transformed) and $\mathrm{Tb}$ at rest and during activity. At rest, there was a 1 inear increase in $\log \mathrm{V} 02$ with a constant Q10 of approximately 1.75. The Q10 with activity decreased from 2.8 in the $10^{\circ} \mathrm{C}-20^{\circ} \mathrm{C}$ interval to 2.3 in the $20 \mathrm{C}-30 \mathrm{C}$ interval. There were significant increases in V02 with temperature for resting and maximally exercised toads.

\section{Blood Viscosity}

Measurements of viscosity at the temperatures used in this study for toad blood at hematocrits between $20 \%$ and $25 \%$ are given in Table IV. Values were determined at a shear rate of $450 \mathrm{sec}^{-1}$. Blood viscosity decreased from $4.85 \mathrm{cP}$ at $10^{\circ} \mathrm{C}(\mathrm{Hct}=21 \%)$ to $2.2 \mathrm{cP}$ at $30^{\circ} \mathrm{C}($ Hct $=23 \%)$. The product of blood flow rate and blood viscosity is shown in Figure 11. Over the $10^{\circ} \mathrm{C}-30^{\circ} \mathrm{C}$ interval, the product of blood flow and viscosity was constant for resting animals. During maximal

exercise there were significant increases $(P<.05$; paired $t$-test $)$ in the product of blood flow and viscosity at $20^{\circ} \mathrm{C}$ and $30^{\circ} \mathrm{C}$ over resting values. However, there was no significant increase during exercise at $10^{\circ} \mathrm{C}$

\section{DISCUSSION}

Heart Rate, Systemic Arch Pulse Volume and Oxygen Consumption

Temperature and activity affected heart rate measurements in this study in a manner typical of anurans (Seymour, 1973; Weathers, 1975). 
The resting heart rates for $\underline{B}$. marinus measured here agree closely with those of McDonald et al.(1980) and Withers et al.(1984) (Figure 5). Individual toads at $10^{\circ} \mathrm{C}$ showed significant reductions in SAPV during activity and exhibited the largest changes in SAPV at heart rates below 20 beats $\min ^{-1}$ (Figure 7 ). At heart rates above 20 beats min ${ }^{-1}$, pulse volume decreased only slightly with elevated heart rate. This suggests that at low Tb and heart rate, the contribution of stroke volume to $\nabla 02$ may be greater than at higher heart rates. Over the wide range of heart rates examined here (15-115 beats $\left.\min ^{-1}\right)$, there appears to be a slight reduction in the contribution of stroke volume to increased v02 (Figures 8,9). Withers et al.(1984) also found a small negative $(-2 \%)$ contribution of pulse volume for $\underline{B}$. marinus during activity at $20^{\circ} \mathrm{C}$. The small contributive effect of stroke volume to increased $\nabla 02$ has also been noted for a lizard at various temperatures (Tucker, 1966) and a flying pigeon (Butler et al., 1977).

The results here suggest that toads do not appreciably alter stroke volume under normal physiological circumstances, with a possible exception at low heart rates at $10^{\circ} \mathrm{C}$. It has been suggested that stroke volume must remain relatively constant in order to achieve a high degree of functional separation between oxygenated and deoxygenated blood due to the incompletely divided ventricle of amphibian hearts (Withers et al., 1984). Tazawa et al.(1979) demonstrated that separation efficiency decreases significantly in bullfrogs if the pericardial sac is opened, allowing increased ventricular filling. The results presented here would support this hypothesis. 


\section{Figure 7.}

Systemic arch pulse volume $\left(\mathrm{ml} \mathrm{kg}^{-1}\right)$ as a function of heart rate (beats $\min ^{-1}$ ) for resting (open symbols) and active (closed symbols) toads at $10^{\circ} \mathrm{C}$. 


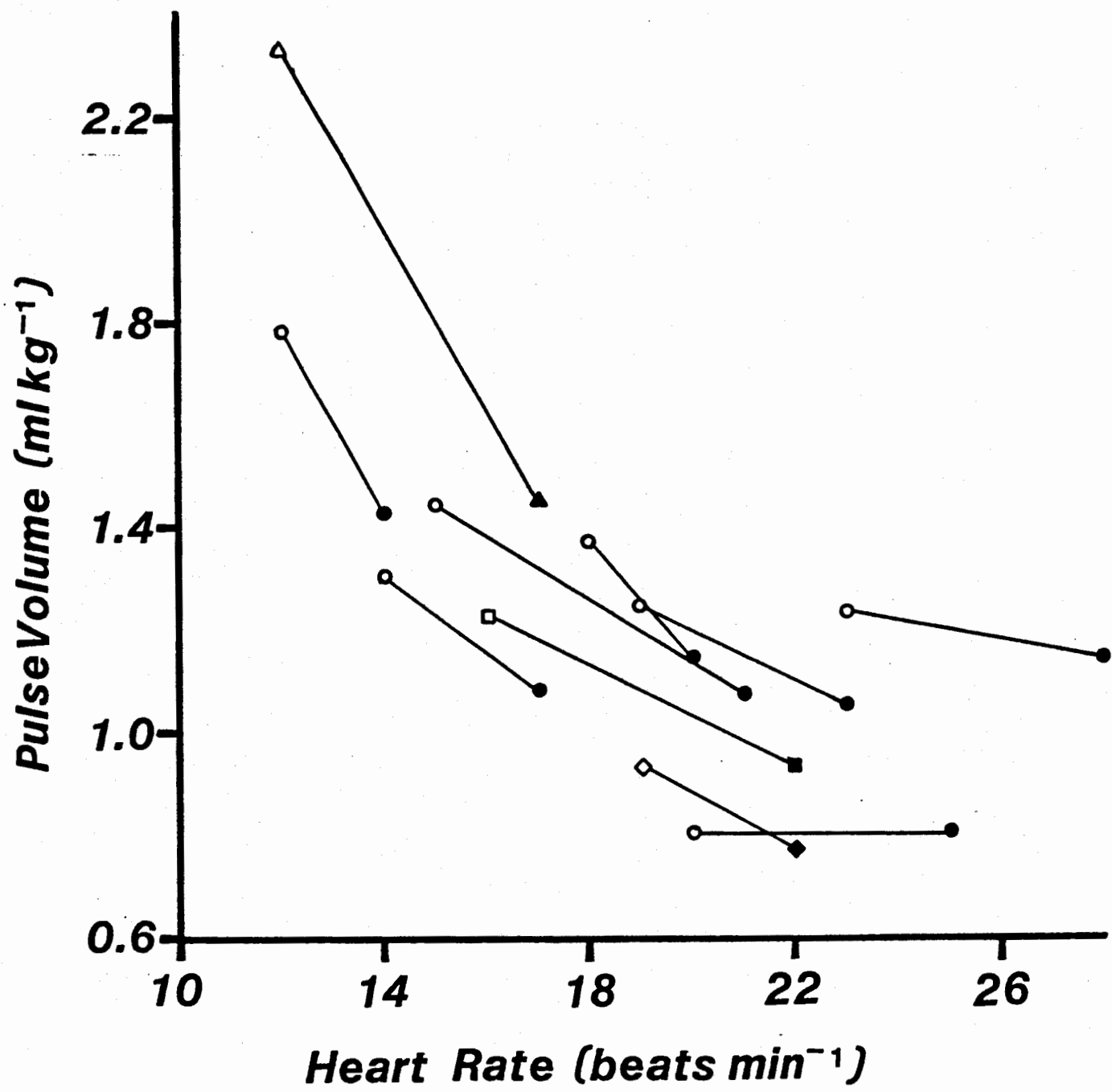




\section{Figure 8.}

Systemic arch pulse volume $\left(\mathrm{ml} \mathrm{kg}^{-1}\right)$ as a function of heart rate (beats $\min ^{-1}$ ) for $\underline{B}$. marinus at $20^{\circ} \mathrm{C}$. Regression 1 ines are drawn for animals at which more than two values for pulse volume and heart rate were measured. 


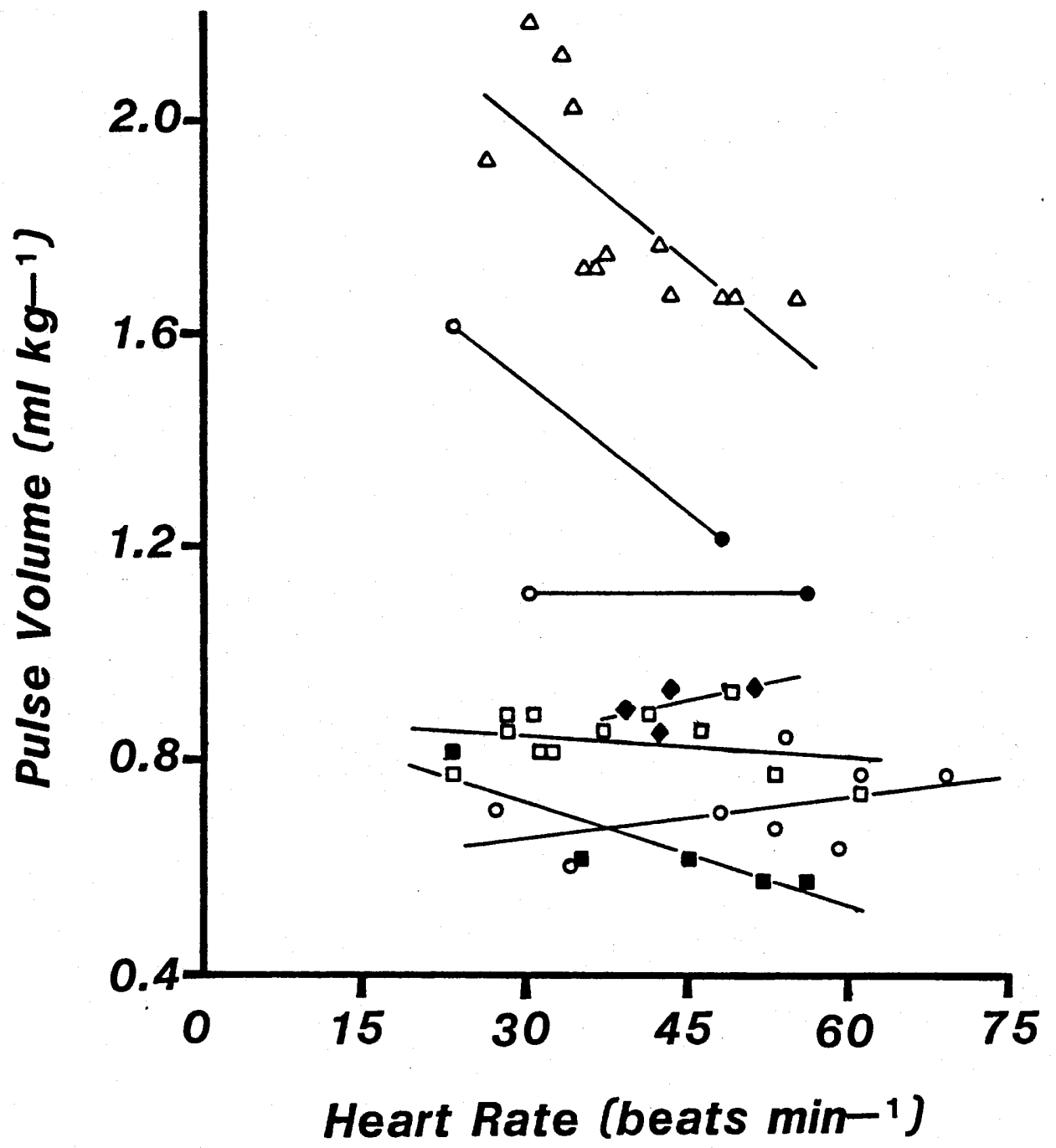

4 


\section{Figure 9.}

Systemic arch pulse volume $\left(\mathrm{ml} \mathrm{kg}^{-1}\right)$ as a function of heart rate (beats $\min ^{-1}$ ) for $\underline{B}$. marinus at $30^{\circ} \mathrm{C}$. Regressions are indicated by dashed lines for animals at which more than two values were measured. 


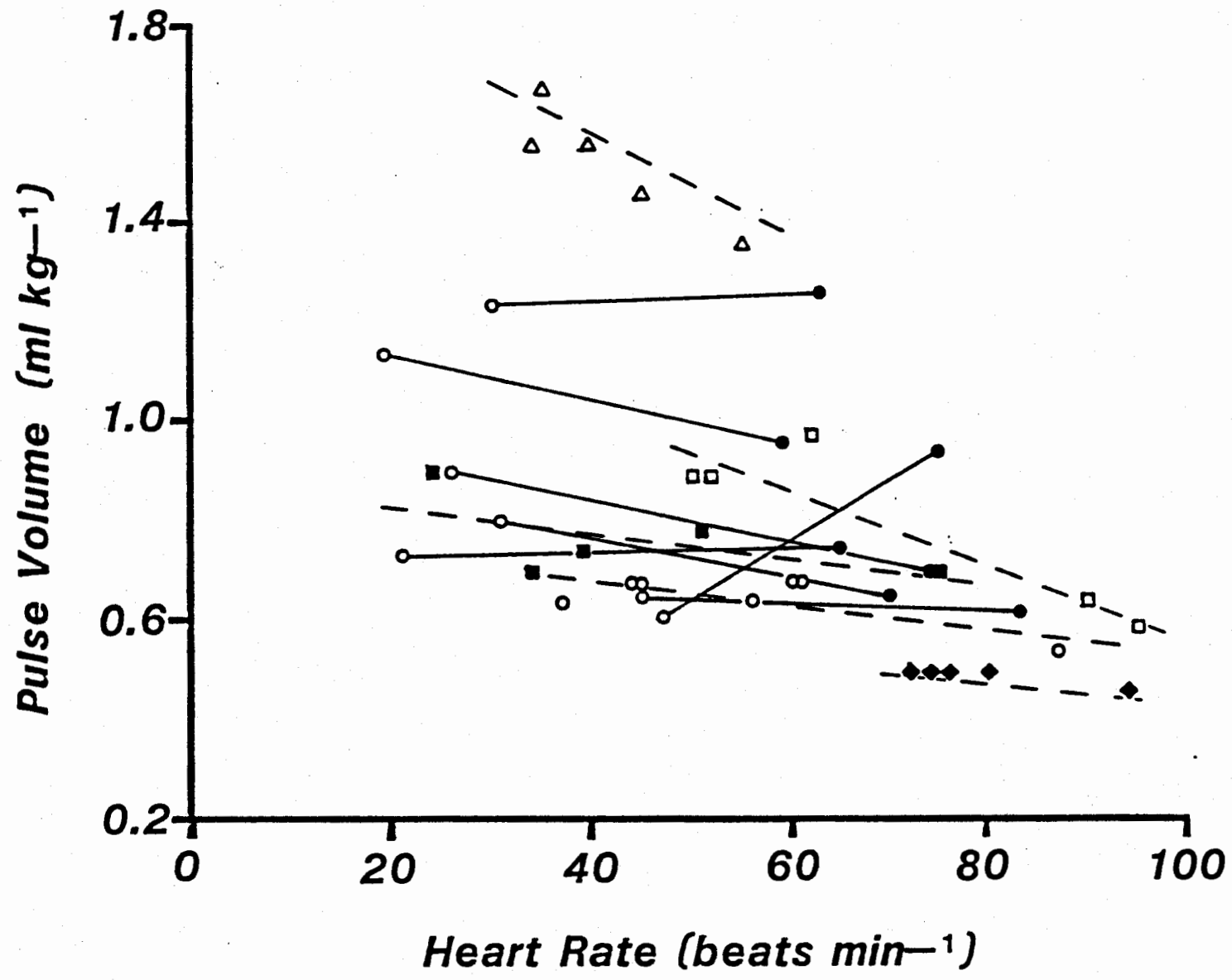


Since temperature significantly increased heart rate during rest and activity, it would appear that increased cardiac output in amphibians is primarily augmented by heart rate and not stroke volume. This is contrary to the conclusions of Carey (1979) who calculated (based on the equations of Gatten, 1974) a decline in the percentage contribution of heart rate during activity in $\underline{B}$. boreas from $5 \%$ at $5^{\circ} \mathrm{C}$ to $1.7 \%$ at $30^{\circ} \mathrm{C}$. Although she did not measure blood flow rates or A-V differences, she concluded that stroke volume and/or $A-\nabla$ difference must contribute the most to increased $v 02$ during activity. Using the method of Gleeson et al.(1980), the calculated percentage contributions of heart rate to $\nabla 02$ in $\underline{B}$. marinus in this study at $10^{\circ} \mathrm{C}, 20^{\circ} \mathrm{C}$ and $30^{\circ} \mathrm{C}$ are $4.3 \%, 18 \%$ and $10 \%$, respectively. These values are somewhat higher than those of Carey (1979) due to computational differences, and in concert with SAPV data suggest that increased A- $\nabla$ difference comprises the bulk of the contribution to increased $\mathrm{V} 02$ with activity in amphibians. This conclusion agrees with the findings of Withers et al.(1984). They calculated a modest (18\%) contribution of heart rate and a very large (85\%) contributive effect of $A-\nabla$ difference on $V 02, \max$ for toads at $200^{\circ}$.

The values for standard V02 are much lower than those reported previously for this species (Miller and Hutchinson, 1980), but are comparable to those of Withers et al. $(1984)$ at $20^{\circ} \mathrm{C}$. These values are also similar to resting metabolic rates of bullfrogs over a $5^{\circ} \mathrm{C}-20^{\circ} \mathrm{C}$ interval (Weathers, 1976b). V02max values for toads in this study are, however, lower than those reported by Miller and Hutchinson (1980). There was a constant increase in Q10 of about 1.75 over the entire 
temperature interval for resting animals, which was higher than the Q10 for blood flow (1.5). The discrepancy in Q10 values may suggest that increased metabolic demands with increasing $\mathrm{Tb}$ in toads are primarily being met by increasing A-V 02 difference. Weathers (1976b) found that resting bullfrogs acclimated to $5^{\circ} \mathrm{C}$ and $20^{\circ} \mathrm{C}$ for $2-3$ weeks responded to temperature regimes by changes in cardiac output with little change in A-V difference. The differences in these results may be due to anuran cardiovascular adjustments during short term versus long term Tb changes.

\section{Blood Flow Rates and Viscosity}

Blood flow rates through the systemic arches of resting toads were lower than reported for resting bullfrogs at similar Tbs (Weathers, 19/6b). His values for heart rates at $20^{\circ} \mathrm{C}$ ( 47 beats/min) compared to my toads ( 28 beats/min) suggest that the bullfrogs were not at rest, and this would account for the high blood flow rates he observed. With heart rate discrepancies taken into account, the blood flow rates for toads at $20^{\circ} \mathrm{C}$ are similar to values reported for bullfrogs (Weather $8,1976 \mathrm{~b}$ ).

An obvious, yet often ignored component of blood flow in ectotherms is the potential significance of flow perturbations due to increases or decreases in blood viscosity that accompany changing $\mathrm{Tb}$. The in vitro changes in blood viscosity that occur with temperature are well known in fish (Graham and Fletcher, 1983; Graham et al., 1985), amphibians (Weathers, 1976b; Langille and Cr18p, 1980) and reptiles (Snyder, 1971; Maclean et al., 1975). The influence of viscosity on blood flow through tubes is predicted by the Poiseuille-Hagen flow equation (see Chapter 
Figure 10 .

Mean values for blood flow rate (ml kg-1 min-1) for resting (solid bars) and active (open bars) $\underline{B}$. marinus at $100 \mathrm{C}, 200 \mathrm{C}$ and $300 \mathrm{C}$. Inset boxes indicate \pm 2 S.E. 
1). Since flow is inversely related to viscosity, any increase or decrease in viscosity should be reflected in a proportional decline or elevation in blood flow, respectively. In this study, resting systemic arch blood flow (Table IV; Figure 10) increased with Tb by $1.41 \mathrm{X}$ $(10 \circ \mathrm{C}-20 \circ \mathrm{C}), 1.5 \mathrm{X}(20 \circ \mathrm{C}-30 \circ \mathrm{C})$ and $2.1 \mathrm{X}$ over the entire Tb interval. Interestingly, in vitro blood viscosity measured over the same $\mathrm{Tb}$ interval decreased almost exactly in proportion to blood flow through the systemic arches, as predicted by equation 1. This would suggest that in resting toads, blood flow changes that are observed with changing $\mathrm{Tb}$ can be entirely explained by alterations in blood viscosity (and resistance) in the circulation. If this is true, then the product of blood flow and blood viscosity should be constant for resting toads over the range of Tbs examined here (see Figure 11). In active toads, however, blood flow increased 3.2 fold over the $100 \mathrm{C}-300 \mathrm{C}$ interval indicating that blood viscosity changes cannot account for all of the observed changes in blood flow. The large increases in blood flow with activity relative to viscosity alterations, can be explained primarily by the marked vasodilatation of the vascular beds, which serves to maximally decrease peripheral resistance. Langille and Crisp (1980) suggest that viscosity effects over large (20 C-30 C) intervals in ectotherms are an integral component of the cardiovascular responses seen during heating and cooling. Their viscosity measurements for Rana catesbeiana at equivalent temperatures and hematocrits are very similar to the data presented here (Table IV). It has previously been determined that the rheological behavior of bullfrog blood is quite similar to that of B. marinus (Chapter 1 ). 
Figure 11.

The product of blood flow and blood viscosity (ml $\mathrm{kg}^{-1}$ min-1 cP) as a function of temperature ( $O C$ ) for resting (closed circles) and active (open cirlces) B. marinus. Values are mean \pm S.E. 


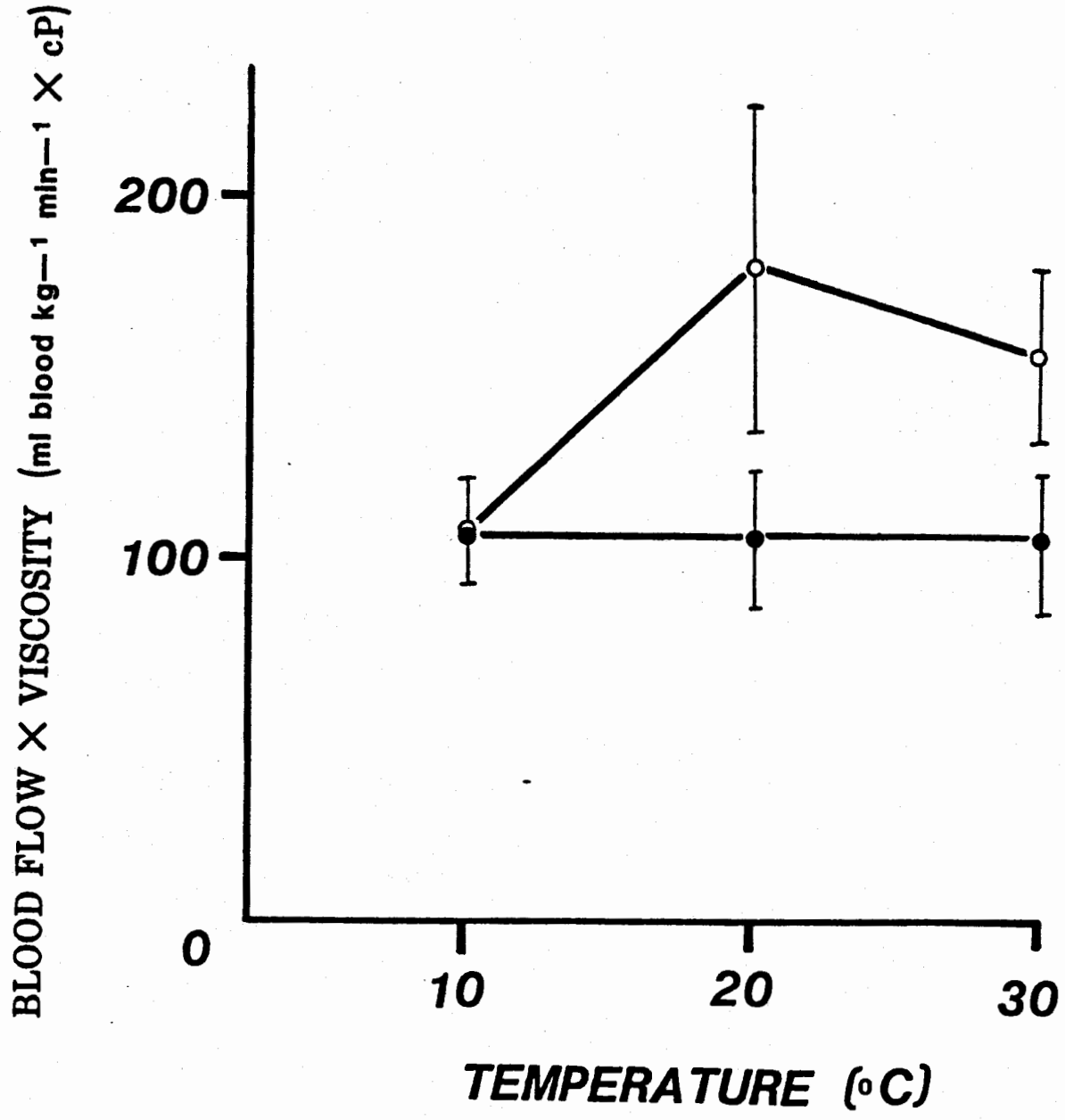


One potential limitation of the above analysis is the extrapolation of in vitro measurements of blood viscosity to the in vivo condition. There are few data available for measurements of blood viscosity in vivo, although Lipowsky et al. (1980) found there to be a close correspondence between in vivo and in vitro viscosity under most flow conditıons and hematocrits. The blood flow-viscosity relationship presented here may therefore reflect in vivo flow conditions. Resting animals may also alter total peripheral resistance (TPR) as metabolic conditions warrant, but the results here indicate that resting toads apparently do not. The variations observed in amphibian cardiovascular dynamics are complicated by the possibility of cardiac shunting of blood preferentially to the pulmocutaneous or systemic branches of the circulation. Langille and Jones (1977) argued that distribution of blood to the periphery is controlled only by vasoactivity of the vascular beds. It has also been observed in Xenopus that increased pulmocutaneous flow occurs during normal breathing movements, caused by marked vasodilation in the pulmonary vascular beds (Emilio and Shelton, 1972). 
SUMMARY

1. In vitro measurements of nucleated versus enucleate RBCs indicate that enucleate cells are more deformable which results in lower values of blood viscosity at higher hematocrits. Lower viscosity may be advantageous in allowing higher blood flow rates and oxygen delivery to the tissues.

2. Except for elephant seal blood, the normal hematocrit for each species was equivalent to the predicted optimal hematocrit for oxyen transport determined in vitro. This verifies previous work concerning optimal hematocrit theory, but also points out that not all vertebrates possess hematocrits equal to the predicted optimal value.

3. Amphiuma blood appeared to have a higher yield stress than other vertebrate blood measured. It is not known why this might occur but may be due in part to the larger RBC size of amphiuma cells relative to other RBCs.

4. The largest contribution to increased v02 during exercise in Bufo marinus at any temperature was the increase in $A-\nabla 02$ difference.

5. Systemic arch pulse volume remained nearly constant over a large range of heart rates indicating that stroke volume does not significantly enhance cardiac output in toads. Heart rate had small to moderate contributions to increased 
v02 with activity.

6. Changes in blood flow rates in vivo with temperature in resting toads could be predicted on the basis of known in vitro changes in blood viscosity, suggesting that some circulatory changes with changing $\mathrm{Tb}$ may be the result of passive alterations in viscosity. 


\section{REFERENCES CITED}

Altman, P.L. and D.S. Dittmer. Biology Data Book. Federation of Societies for Experimental Biology, Washington pp. 268-270. 1964.

Barbee, J.H. (1973). The effect of temperature on the relative viscosity of human blood. Biorheology 10:1-5.

Butler,P.J., N.H. West and D.R.Jones (1977). Respiratory and cardiovascular responses of the pigeon to sustained, level flight in a wind-tunnel. J. Exp. Biol. 71:7-26.

Carey, C. (1979). Aerobic and anaerobic energy expenditure in montane Bufo b. boreas and Rana pipiens. Oecologia 39:213-228

Cerny,L.C., F.B. Cook and C.C. Walker (1962). Rheology of Blood. Am. J. Physiol. 202:1188-1194.

Chen, R.Y.Z. and S. Chien (1978). Hemodynamic functions and blood viscosity in surface hypothermia. Am. J. Physiol. 235:H136H1 43 .

Chien, S., S. Usami, R.J. Dellenback and M.I. Gregersen (1967). Blood Viscosity: Influence of erythrocyte deformation. Science 157:827-829.

Chien, S., S. Usami, R.J. Dellenback and M.I. Gregersen (1970). Shear-dependent interaction of plasma proteins with erythrocytes in blood rheology. Am. J. Physio1. 214:143-153.

Chien, S., S. Usami, R. Dellenback and C. Bryant (1971). Comparative hemorheology- hematological implications of species differences in blood viscosity. Biorheology 8:35-57.

Chien, S. (1972). Rheology of blood. In Theoretical Basis and Clinical Application. Karger-Basel. pp.1-45.

Chren, S. (1975). Biophysical behavior of red cells in suspensions. In The Red Blood Cell. 2nd ed., Vol. 2. Academic Press : New York.

Crowell J.W. and E.E. Smith (1967). Determinant of the optimal hematocrit. J. App1. Physiol. 22:501-504.

Emilio, M.G. and G. Shelton (1972). Factors affecting blood flow to the lungs in the amphibian, Xenopus laevis. J. Exp. Biol. 
$56: 67-77$.

Gaehtgens, P., F. Schmidt and G. Will (1981a). Comparative rheology of nucleated and non-nucleated red blood cells I. Microrheology of avian erythrocytes during capillary flow. Pflugers Arch. 390:278-282.

Gaehtgens, P., G. Will and F. Schmidt (1981b). Comparative rheology of nucleated and non-nucleated red blood cells II. Properties of avian red cell suspensions in narrow capillaries. Pflugers Arch. 390:283-287.

Gatten, R.E. (1974). Percentage contribution of increased heart rate to increased oxygen transport during activity in Pseudemys scripta, Terrepene ornata and other reptiles. Comp. Biochem. Physiol. 48A:649-652.

Gleeson, T.T., G.S. Mitchell and A.F. Bennett (1980). Cardiovascular responses to graded activity in the 1 izards Varanus and Iguana. Am. J. Physiol. 239:R174-R179.

Goldsmith, H.L. and R. Skalak (1975). Hemodynamics. Ann. Rev. Fluid Mech. 213-247.

Gornal1, A.G., C.J. Bardawill and M.M. David (1949). Determination of serum proteins by means of the biuret reaction. J. Biol. Chem. 177:751-766.

Graham, M.S. and G.L. Fletcher (1983). Blood and plasma viscosity of winter flounder:influence of temperature, red cell contration, and shear rate. Can. J. Zool. 61:2344-2350.

Graham, M.S., G.L. Fletcher, and R.L. Haedrich (1985). Blood viscosity in arctic fishes. J. Exp. Zool. 234:157-160.

Guard, C.L. and D.E. Murrish (1975). Effects of temperature on the viscous behavior of blood from antarctic birds and mammals Comp. Biochem. Physiol. 52A:287-290.

Halikas, G. (1971). Cryorheology of reindeer blood. Biorheology 9:105-114.

Hillman, S.S. (1976). Cardiovascular correlates of maximal oxygen consumption in anuran amphibians. J. Comp. Physiol. 109:199-207.

Hillman, S.S., V.H. Shoemaker, R. Putnam and P.C. Withers (1979). Reassessment of aerobic metabolism in amphibians during activity. J. Comp. Physio1. 129:309-313.

Hillman, S.S., P.C. Withers, M.S. Hedrick and P.B. Kimmel (1985). 
The effects of erythrocythemia on blood viscosity, systemic oxygen transport and maximal rates of oxygen consumption in an amphibian. J. Comp. Physiol. In Press.

Langille, B.I. and D.R. Jones (1977). Dynamics of blood flow through the hearts and arterial systems of anuran amphibia. J. Exp. Biol. $68: 1-17$.

Langille, B.L. and B. Crisp (1980). Temperature dependence of blood viscosity in frogs and turtles: effect on heat exchange with environment. Am. J. Physiol. 239:R248-R253.

Lipowsky, H.H., S. Usami, and S. Chien (1980). In vivo measurements of "apparent viscosity" and microvessel hematocrit in the mesentery of the cat. Microvascular Res.19:297-319.

Maclean, G.S., A.K. Lee and P.C. Withers (1975). Haematological adjustments with diurnal changes in body temperature in a lizard and a mouse. Comp. Biochem. Physiol. 51A:241249.

Maclean, G.S. (1981). Blood viscosity of two mammalian hibernators: Spermophilus tridecemlineatus and Tamias striatus. Physiol. Zool. 54:122-131.

Merrill, E.W., E.R. Gilliland, G. Cokelet, H. Shin, A. Britten and R.E. Wells (1963). Rheology of human blood, near and at zero flow- Effects of temperature and hematocrit level. Biophys. J. 3:199-213.

Merril1, E.W. (1969). Rheology of blood. Ann. Rev. Physiol. 49: 863-883.

Miller, R. and V.H. Hutchinson (1980). Aerobic and anaerobic scope for activity in the giant toad, Bufo marinus. Physiol. Zool. $53: 170-175$.

Murray, J.F., P. Gold and B.L. Johnson, Jr. (1962). Systemic oxygen transport in induced normovolemic anemia and polycythemia. Am. J. Physio1. 203:720-724.

Ridgway, S.H. (1972). Mammals of the Sea-Biology and Medicine. S.H. Ridgway, ed. Charles C. Thomas. Springfield, I1l.

Seymour, R.S. (1973). Physiological correlates of forced activity and burrowing in the spadefoot toad, Scaphiopus hammondii. Copeia 1:103-115.

Skalak, R., Chen, P.H. and S. Chien (1972). Effect of hematocrit and rouleaux on apparent viscosity in capillaries. Biorheology 9:67-82. 
Snyder, G.R. (1971). Influence of temperature and hematocrit on blood viscosity. Am. J. Physiol. 220:1667-1672.

Snyder, G.K. and W.W. Weathers (1977). Hematology, viscosity, and respiratory functions of the whole blood of the lesser mouse deer, Tragulus javanicus. J. Appl. Physiol. 42:673-678

Stone, H.O., H.R. Thompson and R. Schmidt-Nielsen (1968). Influence of erythrocytes on blood viscosity. Am. J. Physiol. 214:913-918.

Taigen, T.L., S.B. Emerson and F.H. Pough (1982). Ecological correlates of anuran exercise physiology. Oecologia 52: 49-56.

Tazawa, H., M. Mochizuki and J. Piiper (1979). Respiratory gas transport by the incompletely separated double circulation in the bullfrog, Rana catesbeiana. Respir. Physiol. 36:77-95

Tucker, V.A. (1966). Oxygen transport by the circulatory system of the Green Iguana (Iguana iguana) at different body temperatures. J. Exp. Bio1. 44:77-92.

Usami, S., S. Chien and M.I. Gregersen (1969). Viscometric characteristics of blood of the elephant, man, dog, sheep and goat. Am. J. Physiol. 217:884-890.

Usami, S., V. Magazinovic, S. Chien and M.I. Gregersen (1970). Viscosity of turkey blood: rheology of nucleated erythrocytes. Microvas. Res, 2:489-499.

Viscor, G., J. Fuentes and J. Palomeque (1984). Blood rheology in the pigeon (Columba livia), hen (Gallus gallus domesticus) and black headed gull (Larus ridibundus). Can. J. Z001. 62:2150-2156.

Weathers, W.W. (1975). Circulatory responses of Rane catesbeiana to temperature, season and previous thermal history. Comp. Biochem. Physiol. 51A:43-51.

Weather8, W.W. (1976a). Influence of temperature on the optimal hematocrit of the bullfrog (Rana catesbeiana). J. Comp. Physio1. $105: 173-184$.

Weathers, W.W. (1976b). Influence of temperature acclimation on oxygen consumption, haemodynamics and oxygen transport in bullfrogs. Aust. J. Zoo1. 24:321-330.

Withers, P.C., S.S. Hillman, L.A. Simmons and A.C. Zygmunt (1984) Cardiovascular adjustments to enforced activity in the anuran amphibian, Bufo marinus. Manuscript. 
Zar (1980) Biostatistical Analysis. Englewood Cliffs:Prentice Hall 